\title{
A REVIEW ON BIODIESEL FEEDSTOCKS AND PRODUCTION TECHNOLOGIES
}

\author{
ABDALLAH S. ELGHARBAWY ${ }^{*}$,WAGIH. A. SADIK *, OLFAT M. SADEK ${ }^{*}$, MOSAAD A. KASABY * \\ Materials Science Department, Institute of Graduate Studies and Research (IGSR), Alexandria University, 163 Horrya Avenue, P.O. Box 832, Shatby , 21526 \\ Alexandria, Egypt.
}

\begin{abstract}
Biodiesel is a long-chain fatty acid ester made from renewed and biological raw materials such as used cooking, animal fat, vegetable oil, and algae. Biodiesel is a renewable and clean fuel as it reduces carbon monoxide, carbon dioxide, hydrocarbons, and particulate matter emissions compared with petroleum-based diesel fuel. Production of biodiesel from renewable resources is done through the transesterification reaction at which the organic group (alkyl) of alcohol is substituted with the organic group of a triglyceride- the main component of the feedstock - producing fatty acid alkyl ester (biodiesel) and crude glycerol. Biodiesel can be used in pure form (B100) or may be blended with petroleum diesel at any concentration if its specifications is identical to the international standard specifications provided by American standard for testing materials (ASTM) or EN14214 in the European Union for alternative fuels. In this paper, the different types of biodiesel feedstocks, feedstocks treatment methods, and biodiesel production technologies are reviewed and discussed.
\end{abstract}

Keywords: Biodiesel, feedstocks, transesterification types.

\section{INTRODUCTION}

Biodiesel is an alkyl ester made from renewable feedstocks such as animal fat wastes, vegetable oil, and algae. Besides, biodiesel composition and properties are comparable to that of petro-diesel fuel ${ }^{[1]}$. Diesel or petro-diesel is a nonrenewable fossil fuel that is derived from crude oil and it is likely to be exhausted in the future ${ }^{[2]}$. As diesel made from non-renewable resources, this leads to a raise in energy costs especially with the decline of crude oil production ${ }^{[3]}$. Whereas, biodiesel is produced from its feedstock through a transesterification reaction that includes the exchanging of glycerides (the main component of feedstock) organic group with the organic group of an alcohol to produce biodiesel and glycerol as a co-product ${ }^{[4,5]}$. Table 1 shows the composition and properties of biodiesel as well as diesel ${ }^{[6,7]}$.

Table 1. The composition and properties of biodiesel and diesel.

\begin{tabular}{|c|c|c|c|}
\hline Property & Units & $\begin{array}{c}\text { Diesel fuel } \\
\text { ASTM D975 }\end{array}$ & $\begin{array}{c}\text { Biodiesel } \\
\text { ASTM D6751 }\end{array}$ \\
\hline Composition & & $\begin{array}{c}\text { Hydrocarbon } \\
\left(\mathrm{C}_{10}-\mathrm{C}_{21}\right)\end{array}$ & FAME $\left(\mathrm{C}_{12}-\mathrm{C}_{22}\right)$ \\
\hline Oxygen content & $\%$ & 0 & 11 \\
\hline Hydrogen content & $\%$ & 13 & 12 \\
\hline $\begin{array}{c}\text { Density @ } 15^{\circ} \mathrm{C} \\
\text { @ } 400^{\circ} \mathrm{C}\end{array}$ & $\mathrm{g} / \mathrm{cm}^{3}$ & 0.85 & $0.86-0.90$ \\
\hline Kinematic Viscosity & $\mathrm{C} . \mathrm{st}$ & 2.5 & $1.9-6$ \\
\hline Flash point & ${ }^{\circ} \mathrm{C}$ & $60-80$ & $100-170$ \\
\hline Sulphur Content & $\mathrm{ppm}$ & 10 & 500 \\
\hline Calorific value & $\mathrm{MJ} / \mathrm{kg}$ & 45 & 37.3 \\
\hline Cetane number & --- & $40-55$ & $48-65$ \\
\hline
\end{tabular}

Biodiesel is one of the common biofuels used in many countries as it is utilized in the US, Brazil, Indonesia, Malaysia, France, Germany, and other European countries in large quantities. The global production of biodiesel raised from 3.5 million tons in 2005 to 16 million tons in 2010 , reached 29 million tons in 2016, and expected to exceed 36.5 million tons in $2025^{[8]}$. Many experts assume that there will be an increased global production of biodiesel to meet future demands for biodiesel that will be around 277 million tons per year by $2050^{[9,10]}$. Clean burning, good lubrication efficiency, low aromatics content, low sulfur content, high cetane number, and low pour point characterize biodiesel over petrodiesel. The distinctive properties of biodiesel decrease the emissions of particulate matter (PM), carbon monoxide (CO), and hydrocarbons $(\mathrm{HC})$ in the exhaust gas. Therefore, biodiesel is an eco-friendly fuel ${ }^{[11,12]}$.
The raw material is a very important perspective in biodiesel industry as the cost of biodiesel is greatly affected by the processed raw material being used. Nowadays, feedstock equals at least $80 \%$ of the costs associated with biodiesel production $^{[13]}$. Around $95 \%$ of the biodiesel production globally is made from edible oils which considered an unrequired status, as the world is experiencing from a food problem ${ }^{[14]}$. Therefore, the new trend now is to make biodiesel from cheap non-edible oil ${ }^{[15]}$. There are some feedstocks distinguished by high productivity in biodiesel production because of the high content of triglycerides such as palm, jatropha, microalgae, tallow coconut, and waste cooking oil ${ }^{[16]}$. Feedstocks of biodiesel can be divided into two main categories as below ${ }^{[17]}$ :

1. Edible vegetable oil: soybean, peanut, sunflower, palm oil, and coconut oil.

2. Non-edible vegetable oil: rapeseed, jatropha, jojoba, and waste cooking oil.

Biodiesel is produced from vegetable oil through a transesterification reaction that is the reaction of triglycerides with alcohol in a specified time, temperature, mixing rate, and in the presence of catalyst producing fatty acids alkyl esters (biodiesel) and crude glycerol ${ }^{[18,19]}$. Methanol, ethanol, or butanol are the main alcohols used in transesterification reactions ${ }^{[20]}$. There are four types of transesterification reactions alkaline catalyzed, acid-catalyzed, enzymecatalyzed, and non- catalyzed supercritical methanol transesterification ${ }^{[1,21]}$. Industrially, the alkaline or base-catalyzed transesterification is the most common process because it is the easiest and fastest process ${ }^{[22,23]}$.

FFAs are undesired compounds in feedstock since they react with base catalyst to produce carboxylic acid salts (soap) and water. Soap formation reaction is the biggest barrier to the biodiesel industry because soap contracts biodiesel yields, increases the viscosity of products, forms emulsions and makes separation of glycerol from biodiesel more difficult ${ }^{[24]}$. Therefore, high FFAs content destroys the transesterification reaction. Feedstock with FFAs more than $1 \mathrm{wt}$ \% of oil is not processed directly by the base catalyst transesterification and treatment steps should be applied on feedstock. In contrast, feedstock with FFAs less than $1 \mathrm{wt}$. $\%$ can be processed directly. Equation 1 shows the reaction of base catalyst (sodium hydroxide) with FFA to produce soap and water ${ }^{[25]}$.

$$
\begin{array}{cccc}
\mathrm{R}-\mathrm{COOH} & +\mathrm{NaOH} & \longrightarrow & \text { RCOONA } \\
\text { FFA } & \text { Catalyst } & \text { Soap } & \mathrm{H}_{2} \mathrm{O} \\
\text { Water }
\end{array}
$$

In Industrial application, acid esterification is the most common treatment process to decrease FFAs. Glycerol esterification or glycerolysis is an effective process to reduce FFAs but it is not known as acid esterification. Glycerolysis is able to decrease FFAs in low quality feedstock in the absence of methanol and vacuum stripping steps ${ }^{[26]}$. Acid treatment is done by the reaction alcohol with FFAs using acid as a catalyst to produce biodiesel and water, thus the FFA content goes down. This treatment process is used in the case of FFAs content in the raw material is more than $1 \mathrm{wt} . \%{ }^{[27]}$. In the acid treatment one mole of methanol reacts with one mole of FFAs to achieve the reaction, thus a high 
quantity of methanol is needed to complete the reaction. Equation 2 shows the reaction of alcohol (methanol) with FFA to produce ester and water ${ }^{[26]}$.

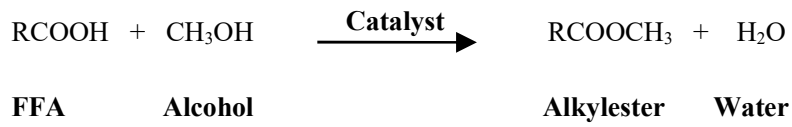

Glycerolysis or glycerol esterification is a treatment process that has the ability to convert FFAs to glycerides. Glycerolysis includes the reaction of FFAs and glycerol to glycerides and water (equation 3). The formed glycerides are then converted to biodiesel using the alkaline transesterification ${ }^{[28]}$. In glycerolysis treatment, low quantity of glycerol as one mole of glycerol is required with three moles of FFAs to achieve the treatment. Equation 3 shows the glycerolysis of FFAs to produce triglyceride and water ${ }^{[29]}$.

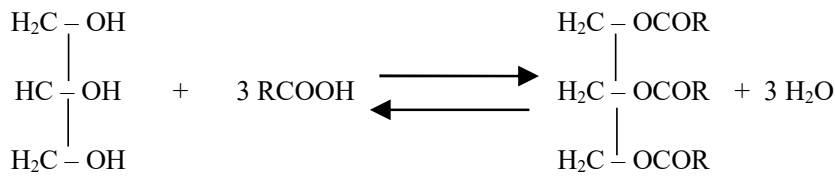

Glycerol Fatty acid $\quad$ Triglyceride Water

The glycerolysis process is not common in the biodiesel production since it requires using expensive metallic catalysts at high temperature that may reach to $220{ }^{\circ} \mathrm{C}{ }^{[30-32]}$. Glycerolysis is commonly used in other industries to produce surfactants and emulsifiers as in the food, cosmetics, or pharmaceutical industries. Crude glycerol - a byproduct from biodiesel production- can be used in glycerolysis reaction but after its treatment as it contains many impurities and its $\mathrm{pH}$ is high.

\section{BIODIESEL FEEDSTOCKS}

Biodiesel can be made from more than 300 types of edible and non-edible vegetable oils ${ }^{[33,34]}$. Most of these feedstocks have a high productivity of biodiesel due to the high concentration of triglycerides ${ }^{[35]}$.

\subsection{Edible Oil}

Edible oil is produced from vegetable resources; it is used mainly for direct human consumption as food intake. It contains various nutritional ingredients so it is healthy and hygienic ${ }^{[36]}$. The extraction of edible oil from its resources usually does not need any chemical processing. Economically, it is more expensive than non-edible due to the limited supply and high demand. The most common edible oil feedstocks that used for biodiesel production are palm, soybean, sunflower, rapeseed and peanut oils ${ }^{[15,37]}$.

\subsubsection{Palm Oil}

Palm oil is an important edible oil as $70 \%$ to $90 \%$ of palm oil is utilized in food industries and the rest is used in industrial applications ${ }^{[38]}$. Palm oil has a strong productivity of biodiesel as 1.25 liter of palm oil produces 1 liter of biodiesel ${ }^{[39]}$. Palm oil is extracted from the seeds of the palm, it is also have an oil content which reaches $20-21 \%$ wt. ${ }^{\left[{ }^{[40]}\right.}$. Palm oil has to be treated before transesterification reaction to remove solid particles, water, color and odor, after treatment of palm oil the free fatty acid becomes $0.1 \%$. Malaysia and Indonesia are the biggest producers of palm oil ${ }^{[16]}$.

\subsubsection{Soybean Oil}

Soybean oil is a vital edible oil because of its many health advantages. The global production of soybean oil is 222 million tons and is mainly produced in the USA, Brazil, and East Asia. Biodiesel is produced mainly in the USA from soybean oil, the production of one liter biodiesel requires 1.3 liter of soybean oil $^{[38]}$.

\subsubsection{Rapeseed Oil}

Rap or canola is yellow flower that is planted mainly in Europe and Canada. It is used as animal food, rapeseed oil is characterized by high productivity as 1.1 liter of rapeseed oil produces 1 liter of biodiesel ${ }^{[41]}$.

\subsection{Non Edible Oil}

Non-edible oil is the oil that is not valid as a food for human beings as it is not healthy or hygienic, it is used mainly in industrial applications such as biofuel, soap, detergent, and paintings industries ${ }^{[36]}$. Various chemical processes are required to make non-edible oil suitable for a particular application; therefore, it is cheaper to be used in industrial applications. The most common non-edible oil feedstocks that used for biodiesel production are animal tallow castor, jatropha, jojoba, and used cooking oils ${ }^{[15,37]}$. The obstacle of using non-edible oil as a biodiesel raw material is the of high amount of FFAs that react with the base catalyst producing emulsions and soap, thus obstruct the base transesterification reaction ${ }^{[42]}$ and reduce the biodiesel yield. Therefore, the FFAs concentration should be decreased before the transesterification reaction ${ }^{[24]}$.

\subsubsection{Jatropha Oil}

Jatropha oil is extracted from Jatropha seeds. Jatropha is cultivated in elevated temperature weather with sewage water, thus it is a promising resource of biodiesel in Egypt; especially it is the main resource of biodiesel in Asia and Africa. Jatropha oil is characterized by a considerable productivity of biodiesel as its seeds contain oil of 30-35 wt.\% and this oil can be converted to biodiesel ${ }^{[16]}$. Jatropha oil is also used in other applications such as soap, cosmetics, and lubricants industries ${ }^{[26]}$.

\subsubsection{Castor oil}

Castor oil is a vegetable oil produced from castor beans. Castor oil is a colorless or faint yellow liquid with a distinct taste and odor. Its boiling point is $313{ }^{\circ} \mathrm{C}$ with a density of $961 \mathrm{~kg} / \mathrm{m}^{3}$. Castor oil viscosity is about seven times greater than that of other vegetable oils. Biodiesel made from castor oil has an extremely low cloud and pour point, which makes this biodiesel a perfect alternative in winter conditions but the viscosity of biodiesel from castor oil is not within the international standards of biodiesel fuel ${ }^{[43,44]}$.

\subsubsection{Waste Oil (Used cooking oil)}

Used cooking oil is a promising alternative for biodiesel production because of its many advantages. Compared with the other oils, used cooking oil characterized by low price, availability, ease of assemblage from houses and restaurants and renewability ${ }^{[16]}$. Besides, it minimizes the need for using land for biodiesel-producing crops. In many countries, used cooking oils are thrown away unsafely causing environmental pollution despite its importance in biodiesel production. Used cooking oil often contains high amounts of free fatty acids (FFAs). FFAs are undesirable components as they hinder the transesterification reaction and decrease the biodiesel yield so FFAs should be treated and reduced to an appropriate amount ${ }^{[5]}$. In the UK, $89 \%$ of biodiesel is produced from used cooking oil ${ }^{[45]}$.

\subsubsection{Animal fat}

The use of animal fats is promising for the US and European countries because these countries forbidden the use of animal fats as an animal feedstock. Therefore, it presents an economical route to trimming the surplus fats of animal origin in Europe. Animal fats are highly viscous, solid at room temperature and have poor vaporization characteristics because it contains more saturated fatty acids. Animal tallow is a rendered form of beef or mutton fat and is mainly made up of triglycerides. Animal tallow oil is a promising alternative for producing biodiesel because it is a cheap raw material. Since animal tallow is a valueless product to commercial food industries, it avoids the food vs fuel debate ${ }^{[46]}$

\subsubsection{Algae oil}

Different types of algae can be used to produce biodiesel. Generally, algae have $20 \%$ to $80 \%$ oil contents that could be converted into different types of fuels such as kerosene oil and biodiesel. The production of biodiesel from algae is an economical and easy process ${ }^{[47]}$. Different species such as tribonema, ulothrix, and euglena have a good ability for biodiesel production. Algae have oil contents with different compositions depending on the specie types. Some species were identified that they have good fatty acid values. By using a transesterification process, algae oil can be converted to biodiesel ${ }^{[48,49]}$. Table 2 summarizes the difference between edible and non-edible feedstocks ${ }^{[14,44,50]}$. 
Table 2. Differences between edible oil and non-edible oil.

\begin{tabular}{|c|c|c|}
\hline & Edible oil & Non edible oil \\
\hline Source & $\begin{array}{l}\text { Vegetable sources (oil } \\
\text { seed grains and plant } \\
\text { fruits). }\end{array}$ & $\begin{array}{lr}\begin{array}{l}\text { Vegetable } \\
\text { petroleum } \\
\text { animal fat. }\end{array} & \text { oils, } \\
& \text { or } \\
\end{array}$ \\
\hline Use & $\begin{array}{lrr}\begin{array}{l}\text { Direct } \\
\text { consumption }\end{array} & \text { human } \\
\text { intake } & & \text { food } \\
\end{array}$ & $\begin{array}{l}\text { Used to produce } \\
\text { detergent, paintings } \\
\text { soap, fuels, biofuels, }\end{array}$ \\
\hline Composition & $\begin{array}{l}\text { Edible oils have many } \\
\text { nutritional elements }\end{array}$ & $\begin{array}{l}\text { Non-edible oils are not } \\
\text { healthy and valid for } \\
\text { human food. }\end{array}$ \\
\hline $\begin{array}{l}\text { Oil } \\
\text { extraction }\end{array}$ & $\begin{array}{l}\text { Extraction of oil usually } \\
\text { does not need any } \\
\text { chemical treatment }\end{array}$ & $\begin{array}{l}\text { Different chemical } \\
\text { treatment are required to } \\
\text { extract oil. }\end{array}$ \\
\hline Price & High & Low \\
\hline Example & $\begin{array}{l}\text { Such as: soybean, } \\
\text { sunflower, rapeseed, } \\
\text { linseed, safflower, peanut }\end{array}$ & $\begin{array}{l}\text { Such as: castor, } \\
\text { jatropha, jojoba, used } \\
\text { cooking oil and animal } \\
\text { tallow }\end{array}$ \\
\hline
\end{tabular}

\section{FEEDSTOCK TREATMENT METHODS}

\subsection{Acid treatment to decrease FFAs}

Hayyan et al. ${ }^{[51]}$ used sulphuric acid $\left(\mathrm{H}_{2} \mathrm{SO}_{4}\right)$ in the treatment of high FFAs \% in sludge palm oil for biodiesel production. The reaction conditions investigated were methanol to oil ratio ranged from $6: 1$ to $14: 1$, temperature ranged from 40 to $80{ }^{\circ} \mathrm{C}$ ), and reaction time range was from 30 to $120 \mathrm{~min}$. They succeeded to reduce the FFA content from 23 wt. \% to less than 2 wt. \%, using $\mathrm{H}_{2} \mathrm{SO}_{4}$ by 0.75 wt. \% with methanol to oil molar ratio of $8: 1$ at $60{ }^{\circ} \mathrm{C}$ and a reaction time of 60 $\min$

The FFAs of used cooking oil was reduced by Chai et al. ${ }^{[52]}$ from 5 wt. \% to 0.5 wt. $\%$ at the temperature of $65{ }^{\circ} \mathrm{C}$, the methanol to FFAs molar ratio $40: 1$, and $\mathrm{H}_{2} \mathrm{SO}_{4}$ as a catalyst by 10 wt. \%/ wt. \% of feedstock.

Kara et al ${ }^{[53]}$ studied the effect of four various methanol to oil molar ratios (6:1, 9:1, 12:1 and 15:1) on the final FFAs \%, while other parameters were kept fixed (1.5 wt. $\% \mathrm{H}_{2} \mathrm{SO}_{4}, 60{ }^{\circ} \mathrm{C}, 2 \mathrm{~h}$, and a stirring speed of $\left.700 \mathrm{rpm}\right)$. The best optimum conditions were obtained at a molar ratio of 15 : 1 within 160 minutes of reaction. The FFA content reduced from $21 \mathrm{wt} \%$ to $1.5 \mathrm{wt}$. \% with a maximum conversion of $92.6 \%$

The acid treatment method was utilized to lower the FFA of palm oil sludge by alteration of methanol to palm oil sludge molar ratios $(5: 1,10: 1,15: 1,20: 1$, and 25:1) and concentrations of aluminum catalyst $\left(\mathrm{Al}_{2}\left(\mathrm{SO}_{4}\right)_{3} \cdot 14 \mathrm{H}_{2} \mathrm{O}\right)$ by 3 to 7 wt. $\%$ at $60{ }^{\circ} \mathrm{C}$ for $3 \mathrm{~h}$ with $300 \mathrm{rpm}$ of stirring rate ${ }^{[54]}$. The FFAs decreased from 36 wt. \% to 0.82 wt. $\%$ when methanol to oil molar ratio was $20: 1$ with a catalyst weight of 6 wt. \%.

Marchetti et al. ${ }^{[55]}$ studied the acid treatment of FFAs using sulfuric acid as a catalyst and ethanol as alcohol. They showed that the amount of FFA reduced from 10.7 wt. $\%$ to 0.5 wt. $\%$ with a conversion of $96 \%$ at a temperature of 55 ${ }^{\circ} \mathrm{C}$, a catalyst concentration of $2.261 \mathrm{wt} . \%$ and methanol to oil molar ratio $6: 1$.

Thaiyasuit et al. ${ }^{[56]}$ could shrink the amount of FFA through acid treatment process from $20 \mathrm{wt} . \%$ to $3 \mathrm{wt}$. $\%$ at a temperature of $60{ }^{\circ} \mathrm{C}, \mathrm{H}_{2} \mathrm{SO}_{4}$ catalyst of 2.5 wt. $\%$ and methanol to oil molar ratio $6: 1$.

Sadaf et al. ${ }^{[57]}$ investigated the effect of three acids $\left(\mathrm{HCl}, \mathrm{H}_{2} \mathrm{SO}_{4}\right.$, and $\left.\mathrm{H}_{3} \mathrm{PO}_{4}\right)$ on used cooking oil with a FFAs of 2.75 wt. \%. It was found that $\mathrm{H}_{2} \mathrm{SO}_{4}$ was the most efficient catalyst since the FFA decreased to $0.33 \mathrm{wt}$. \% with a conversion of $88.8 \%$ at $60{ }^{\circ} \mathrm{C}$ and $2.5: 1$ methanol to oil molar ratio.

Vieira et al ${ }^{[58]}$ stated that the acid esterification was responsible for metallic equipment corrosion other than consuming large quantities of alcohol to complete the reaction. Consequently, finding a new method for treating high FFAs is essential to develop the biodiesel production process.

\subsection{Glycerolysis treatment to decrease FFAs}

Diaz et al.$^{[32]}$ stated that glycerolysis was successful way to remove of FFAs in the low-quality raw materials. Additionally, its merit was increasing the glycerides amount in the feedstock. In contrast, the other treatment methods made a decrease in the feedstock quantity ${ }^{[50]}$.

Fregolente et al. ${ }^{[59]}$ indicated that the glycerolysis method was able to convert the FFAs to glycerides as glycerol reacted with the FFAs to form monoglycerides, diglycerides, and triglycerides (equation 3). Therefore, the FFAs decreased to suitable amount so that the base transesterification technique can be done without obstacles ${ }^{[30]}$.

Sousa et al. ${ }^{[60]}$ applied a non-catalytic glycerolysis treatment on castor oil with a FFA of 2.5 wt. $\%$ at a temperature of $120^{\circ} \mathrm{C}$, time of $2 \mathrm{hrs}$., a glycerol to oil mass ratio of 1:1. They succeeded to decrease the FFAs from 2.5 to $0.2 \mathrm{wt} . \%$.

B. M. Bhosle ${ }^{[50]}$ lowered the high FFA content of feedstock through the glycerolysis treatment using a lipase enzymes catalyst. The FFA content decreased in a reaction time of $24 \mathrm{~h}$ from 17 to $3 \mathrm{wt}$. \%.

Binhayeeding et al. ${ }^{[61]}$ used glycerolysis reaction to produce glycerides from raw glycerol and palm oil using lipase catalyst. The conditions for the reaction were a molar ratio of glycerol to FFAs $6: 1$, a $100 \mathrm{mg}$ of lipase at $40^{\circ} \mathrm{C}$ and a time of $24 \mathrm{hrs}$. The conversion was $99 \%$ and the produced glycerides were very pure.

The impact of temperature, molar ratio and catalyst concentration on the rate of glycerolysis reaction was discussed by Mostafa et al ${ }^{[62]}$. The temperature ranged from 180 to $260{ }^{\circ} \mathrm{C}$, oil to glycerol molar ratios were $1: 1,1: 2,1: 3$ and a catalyst of zinc chloride $\left(\mathrm{ZnCl}_{2}\right)$ with a concentration ranged from $0.1 \mathrm{wt}$. \% to 0.3 wt. \%. The best conditions obtained were the oil to glycerol molar ratio of $1: 1$, a catalyst concentration of 0.3 wt. $\%$ at a temperature of $195{ }^{\circ} \mathrm{C}$. The conversion achieved of FFAs to glycerides was $99 \%$.

Anderson et al. ${ }^{[28]}$ used two different types of inorganic catalysts zinc aluminum oxide $\left(\mathrm{Zn}-\mathrm{Al}_{2} \mathrm{O}_{3}\right)$ and sodium sulfate $\left(\mathrm{Na}_{2} \mathrm{SO}_{4}\right)$ in glycerol esterification (glycerolysis) of scum derived oil for biodiesel production. The oil had FFAs concentration of $86 \mathrm{wt}$. \%. They found that the zinc-aluminum oxide catalyst experienced a greater catalytic potential than sodium sulfate. The highest conversion achieved at a $\left(\mathrm{Zn}-\mathrm{Al}_{2} \mathrm{O}_{3}\right)$ concentration of 1.8 wt. $\%$, at $238{ }^{\circ} \mathrm{C}$, a glycerol amount of $18 \mathrm{wt}$ \%, in $60 \mathrm{~min}$. The FFAs content reduced from $86 \mathrm{wt}$. $\%$ to 1 wt. $\%$.

Hermida et al. ${ }^{[63]}$ studied the synthesis of glycerides via glycerol esterification of lauric acid (a fatty acid with a 12-carbon atom chain). The effect of temperature, molar ratio, and catalyst concentration on the rate of glycerolysis reaction was investigated. A catalyst of a propyl sulfonic acid functionalized SBA-15 mesoporous ( $\left.\mathrm{HSO}_{3} \mathrm{SBA}-15\right)$ was used in the glycerolysis reaction. The reaction temperature range was from 140 to $160^{\circ} \mathrm{C}$, lauric acid to glycerol molar ratios were $2: 1,4: 1$ with a catalyst concentration ranged from 1 to $5 \mathrm{wt}$. \%. The optimum conditions obtained were a molar ratio of oil to glycerol $4: 1$, a catalyst concentration of $5 \mathrm{wt}$. $\%$, at a temperature of $160{ }^{\circ} \mathrm{C}$. The conversion achieved of FFAs to glycerides was $99 \%$.

Martín et al. ${ }^{[58]}$ demonstrated that glycerolysis might be used as a first step to reduce the FFA content in the low cost and high acid feedstocks for biodiesel production. They used commercial glycerol to decrease the fatty acids over tin (II) chloride. They noticed that the glycerolysis reaction was reversible so that an excess amount of glycerol was applied to direct the reaction in the forward direction and raise the FFA conversion. The optimum conditions that achieved a $90 \%$ conversion of the FFAs were at a catalyst concentration of $0.1 \mathrm{wt} . \%$, excess glycerol of $20 \%$ over the molar ratio in 60 minutes of reaction time.

Gole and Gogate ${ }^{[64]}$ improved glycerolysis reaction conditions by using a microwave technique. They compared the for the microwave approach with the conventional approach. They used the molar ratio of oil to glycerol as 1:2 and zinc acetate catalyst concentration of $0.1 \% \mathrm{wt}$ for the both approaches. They concluded that microwave irradiations decreased the reaction time and reaction temperature as the reaction time reduced from 240 minutes to 25 minutes while the temperature contracted from 200 to $105^{\circ} \mathrm{C}$. 
The glycerolysis reaction is consistent with temperature as it is directly proportional to the temperature but to the limited range as an excessive rise in temperature causes glycerol and oil decomposition other than the great cost of the process from the economic point of view as stated by Supardan ${ }^{[62]}$.

Megawati et al. ${ }^{[65]}$ studied the effect of temperature on glycerolysis reaction using calcium oxide as a catalyst. They noted that the conversion increased sharply in the first 5 minutes followed by a gradual rise to an almost constant value after 20 minutes as after 20 min of reaction no significant conversion occurred. The experiments were done by changing only the temperature while other conditions remained fixed conditions. The FFAs to glycerol molar ratio was $1: 6$ and the mass ratio of calcium oxide to FFA was $1: 25 \mathrm{wt} . \%$ in 20 minutes of reaction time. They could reduce FFAs from $43 \mathrm{wt}$ \% $\%$ to $6.5 \mathrm{wt}$. \% with a FFA conversion of $84.5 \%$ at a temperature of $60{ }^{\circ} \mathrm{C}$ while at $70{ }^{\circ} \mathrm{C}$ the FFA decreased to 6.2 wt. \% with a FFA conversion of $85.3 \%$. The maximum decrease occurred at a temperature of $80{ }^{\circ} \mathrm{C}$ as the final FFA reached 5.8 wt. \% with a FFA conversion of $86.1 \%$.

G. G. Kombe et al. ${ }^{[66]}$ used $\mathrm{NaOH}$ catalyst in the glycerolysis reaction to decrease the FFAs of the jatropha oil. They could decrease the FFAs from 4.6 to 0.07 wt. \% using a catalyst amount of 1.75 wt. \%, a glycerol to oil mass ratio of $2.24 \mathrm{~g} / \mathrm{g}$ at $65^{\circ} \mathrm{C}$ in 73 minutes.

\subsection{Crude glycerol purification for glycerolysis reaction}

Chetpattananondh and Tongurai ${ }^{[67]}$ purified residual glycerol from the biodiesel industry by using hydrochloric acid to neutralize its high alkalinity then it was washed with hot water. The purity of glycerol reached more than $90 \%$.

Anderson et al. ${ }^{[28]}$ represented that the simple way of glycerol purification was done by water washing due to the hydrophilic nature of glycerol. The glycerol was dissolved in water to remove the impurities. Eventually, the glycerol was dried well to eliminate any traces of water by evaporating water at elevated temperature.

Binhayeeding et al. ${ }^{[61]}$ used a neutralization technique to purify crude glycerol from the biodiesel industry that had a $\mathrm{pH}$ of 9 . Sulfuric acid was added to the original waste glycerol to decrease its $\mathrm{pH}$ from 9 to 2 . Three distinct layers formed; an inorganic salt layer on the bottom, a glycerol-rich layer in the middle and a FFAs layer on the top. The glycerol-rich layer was withdrawn and neutralized again with $\mathrm{NaOH}$ to raise its $\mathrm{pH}$ again to 6 , then it was washed with ethanol to remove impurities, acid and alkali traces.

Xiao et al. ${ }^{[68]}$ started the purification procedure of crude glycerol with microfiltration ( $0.45 \mu \mathrm{m}$ pore size) to remove all solid contaminations. Vacuum evaporation was applied to eliminate methanol and water by using a rotary evaporator at $50-90{ }^{\circ} \mathrm{C}$ for more than $2 \mathrm{~h}$. Hydrochloric acid was used to neutralize the waste glycerol until the $\mathrm{pH}$ reached 1 . The acidic glycerol was heated at $90{ }^{\circ} \mathrm{C}$ for more than $2 \mathrm{~h}$. After that, the acidic glycerol was poured into a separating funnel for phase split overnight. The upper layer was FFAs product while the lower layer was acidic glycerol and it was extracted by ether to remove the residual FFAs. The acidic glycerol was neutralized with $\mathrm{NaOH}$ until the $\mathrm{pH}$ reached 7 and filtered to eliminate salts, followed by vacuum evaporation at 90 ${ }^{\circ} \mathrm{C}$ for more than $2 \mathrm{~h}$. A washing step was applied to the neutralized glycerol with ethanol. Finally, the washed glycerol was filtered and all light solvents were evaporated out at $50-90{ }^{\circ} \mathrm{C}$ for more than $2 \mathrm{~h}$. The final purity of glycerol was $99 \%$.

Isahak et al. ${ }^{[69]}$ used phosphoric acid to neutralize the alkalinity of glycerol, then microfiltration was applied to remove small particles. The free ions were removed by ion-exchange techniques. Eventually, vacuum distillation was applied to remove methanol, water, and other solvents that existed in glycerol. The final purity of glycerol was $99 \%$.

\section{BIODIESEL PRODUCTION METHODS}

Transesterification is the process that the organic group (alkyl) of alcohol is substituted with the organic group of a triglyceride without a catalyst or in the presence of a catalyst that may be either acid, base or enzyme. There are four types of the transesterification reaction: acid-catalyzed, base-catalyzed, enzymatic-catalyzed, and non-catalyzed supercritical methanol. The most common type is the base-catalyzed transesterification since it is the fastest reaction, the highest yield, the mildest reaction condition, the lowest cost, the lowest corrosive, and the lowest toxicity. Equation 4 shows the reaction of glyceride transesterification ${ }^{[20]}$.

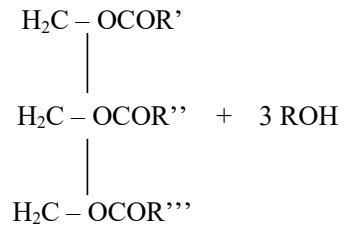

Triglyceride

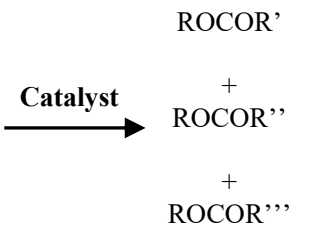

Alkylester<smiles>OCC(O)O</smiles>

Glycerol

\subsection{Base catalyst transesterification}

In the base transesterification process, a glyceride reacts with simple aliphatic alcohol (typically methanol or ethanol) in the presence of a homogenous base catalyst to form fatty acid alkyl esters (biodiesel) and a glycerol ${ }^{[70]}$. Basecatalyzed transesterification is the most common and profitable process among other transesterification processes because it is the cheapest, easiest and fastest process and includes the lowest processing steps ${ }^{[71]}$. Many factors have a noticeable impact on the biodiesel yield and its specification such as alcohol to oil ratio, type of alcohol, purity of alcohol, amount of catalyst, type of catalyst, time of reaction, temperature, pressure, mixing rate, water content in the feedstock, FFAs content in the feedstock and purity of feedstock ${ }^{[72]}$.

The most common catalysts used in transesterification are potassium hydroxide $(\mathrm{KOH})$ and sodium hydroxide $(\mathrm{NaOH}) . \mathrm{KOH}$ is the preferred one as it decreases the tendency for soap formation. Crude glycerol formed when $\mathrm{KOH}$ used as a catalyst is easier to be separated from the produced biodiesel than that formed when $\mathrm{NaOH}$ used. $\mathrm{KOH}$ is also characterized by a low price, great productivity and achieving a moderate condition. Base transesterification can produce $98 \%$ yield at moderate temperatures, pressure and reasonable time ${ }^{[73]}$. It is affected by water and FFAs in the feedstock, it is also affected by solid contaminations in the feedstock such as dust, solid particles, and sands as well as the purity of the reactants so the treating of feedstock before the reaction is necessary ${ }^{[4,74]}$.

Base transesterification is preferable to be used with feedstocks that contain FFAs less than $1 \mathrm{wt} . \%$. The most difficult barriers of base transesterification are the presence of FFAs and water, as FFAs react with catalyst producing soap (equation 1), while water hydrolyzes triglycerides to diglycerides or monoglycerides and FFAs (equation 2). The decomposition of triglycerides leads to the reaction break down in addition to increasing FFAs in the environment of the reaction producing more soaps ${ }^{[74,75]}$. Equation 5 explains the triglyceride dissociation by water to diglyceride and $\mathrm{FFA}^{[76]}$

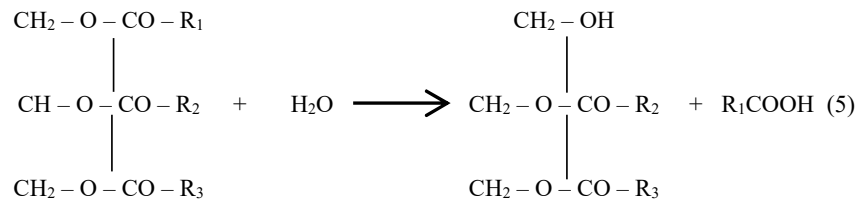

\section{$\begin{array}{llll}\text { Triglycerides } & \text { Water } & \text { Diglycerides } & \text { FFA }\end{array}$}

Base catalyst transesterification is strongly affected by the reaction temperature. As the temperature increases, the rate of reaction also increases and enhances the biodiesel formation. Ferrari et al. reported that the excessive raise of temperature enhances the saponification reaction which becomes significant with increasing the reaction time ${ }^{[77]}$. The reaction temperature should not exceed the boiling point of methanol as it vaporizes and biodiesel is consequently not produced thus the optimum reaction temperature range should be between $40^{\circ} \mathrm{C}$ and $60^{\circ} \mathrm{C}$ as per reported by $\mathrm{Zi}$ et a ${ }^{[78]}$.

Atadashi et al. ${ }^{[26]}$ demonstrated that $\mathrm{KOH}$ was the best catalyst in the transesterification reaction since it gave the highest yield of biodiesel within a limited time. The activity of $\mathrm{KOH}$ and $\mathrm{NaOH}$ was investigated in the transesterification; the result revealed that the $\mathrm{KOH}$ activity was stronger than the $\mathrm{NaOH}$ activity. In addition, the reaction became faster in the case of using 
$\mathrm{KOH}$ and soap formation became lower. Kawentar and Budiman ${ }^{[79]}$ stated that the low methanol amount made the transesterification reaction incomplete and depressed the produced yield. Therefore, an excess amount of alcohol was required to drive the reaction to products formation. They also reported that the minimum methanol to oil ratio required was $3: 1$ to complete the reaction as per stoichiometric ratio and most applied industrial biodiesel processes used methanol to oil ratio $6: 1$. However, $Z$. Yaakob et $\mathrm{al}^{[72]}$ demonstrated that the optimum methanol to waste cooking oil ratio was $9: 1$.

The conversion of FFAs is directly proportional to the reaction time, the optimum reaction time for the transesterification reaction is $2 \mathrm{~h}$ and more time will not affect the final yield. In contrast, excess reaction time motivates the backward reaction, depresses the final yield and produces soaps as reported by Huber et $\mathrm{al}^{[80]}$. C. Komintarachat and S. Chuepeng ${ }^{[81]}$ achieved a biodiesel yield of $88 \%$ through using $\mathrm{KOH}$ as a catalyst with reaction conditions: methanol to oil ratio $15: 1, \mathrm{KOH}$ amount $5 \mathrm{wt} . \%$ at a temperature of $70{ }^{\circ} \mathrm{C}$ within a time of $120 \mathrm{~min}$.

Z. Al-Hamamre and J. Yamin ${ }^{[82]}$ obtained a $98 \%$ biodiesel yield through using $\mathrm{KOH}$ catalyst with reaction conditions: methanol to oil ratio 9.5:1, a $\mathrm{KOH}$ of 1 wt. $\%$ at a temperature of $50{ }^{\circ} \mathrm{C}$ in $20 \mathrm{~min}$, the properties of produced biodiesel were in the standard limits. U. Rashid et al. ${ }^{[83]}$ studied the variation of the reaction parameters on the biodiesel yield. The methanol to oil molar ratio was $(3: 1-$ $21: 1)$, the catalyst concentration ranged from 0.25 to $1.50 \mathrm{wt} . \%$, the temperature ranged from 35 to $65^{\circ} \mathrm{C}$. The best operating conditions were at methanol to oil molar ratio $6: 1 ; \mathrm{KOH}$ catalyst concentration $1.0 \mathrm{wt} . \%$ at a temperature of $65^{\circ} \mathrm{C}$, which achieves a biodiesel yield of $96 \%$. The produced biodiesel properties were within the limits of the American standards for testing material (ASTM-6751).

A. Fadhil et al. ${ }^{[84]}$ produced biodiesel from fish oil through base catalyst transesterification by using two catalysts $\mathrm{KOH}$ and $\mathrm{NaOH}$. The reaction conditions the molar ratio of methanol to oil (3:1, 6:1, 9:1 and 12:1), the catalyst concentration of $(0.25-1.0 \mathrm{wt} . \%)$, the reaction temperature of $\left(32,45\right.$ and $\left.60^{\circ} \mathrm{C}\right)$, and reaction duration $(30,60,90$ and $120 \mathrm{~min})$. The maximum biodiesel yield was $96 \%$ at a $\mathrm{KOH}$ of $0.50 \mathrm{wt} . \%$, a ratio of methanol to oil $6: 1$ at $32{ }^{\circ} \mathrm{C}$ and a time of 60 minutes. M. Harabi et al. ${ }^{[85]}$ used response surface methodology (RSM) to determine the best operating conditions for the transesterification reaction. The methanol to oil molar ratio ranged from $3: 1$ to $12: 1, \mathrm{KOH}$ concentration was from $0.5 \%$ to $2 \mathrm{wt} \% \%$ and the temperature ranged from 25 to $65{ }^{\circ} \mathrm{C}$. The maximum yield was $96 \%$ at methanol to oil molar ratio $7.3: 1, \mathrm{KOH}$ loading $0.5 \mathrm{wt}$. $\% \mathrm{wt}$. and the reaction temperature was at $58.30{ }^{\circ} \mathrm{C}$. The optimum conditions that produced a biodiesel content of $92.76 \%$ were predicted by $\mathrm{W}$. Kawentara and A. Budimanb ${ }^{[79]}$.

The conditions were a temperature of $66.5^{\circ} \mathrm{C}$, the molar ratio of methanol to oil of 6.18:1, and a $\mathrm{KOH}$ concentration of $1 \mathrm{wt}$. \%. E. Rahadianti et al. ${ }^{[86]}$ carried out the transesterification process on used cooking oil by mixing a $\mathrm{KOH}$ amount of 1 wt. $\%$ with methanol to oil ratio $6: 1$ at a temperature of $65^{\circ} \mathrm{C}$ in a time of 75 minutes. The produced biodiesel was purified by washing using hot water at a temperature of $70{ }^{\circ} \mathrm{C}$. The characteristics of the biodiesel based on the best conditions were a density of $0.89 \mathrm{~g} / \mathrm{cm}^{3}$, viscosity 6 C.st, FFAs content 0.11 wt. $\%$ and an acid value of $0.256 \mathrm{mg} \mathrm{KOH} / \mathrm{g}$.

Zayed and $\mathrm{Jehad}^{[82]}$ achieved a $98 \%$ yield through using $\mathrm{KOH}$ as a catalyst with a reaction conditions: methanol to oil ratio is $9.5, \mathrm{KOH}$ is $1 \%$ at temperature $50{ }^{\circ} \mathrm{C}$ and time is $20 \mathrm{~min}$, the viscosity and density of produced biodiesel is 5.8 Cst and $0.877 \mathrm{~g} / \mathrm{cm}^{3}$, respectively. Cholada and Sathaporn ${ }^{[81]}$ achieved a $88 \%$ yield through using $\mathrm{KOH}$ as a catalyst with a reaction conditions: methanol to oil ratio is $15, \mathrm{KOH}$ is $5 \%$ at temperature $70{ }^{\circ} \mathrm{C}$ and time is $120 \mathrm{~min}$.

G. Kafuku and M. Mbarawa ${ }^{[87]}$ interpreted the base transesterification mechanism. The process starts with the base catalyst reaction with alcohol to produce an alkyl-oxide ion and protonated catalyst as in equation 6 . The alkyloxide ion attacks the triglyceride molecule producing unstable intermediate compound as exhibited in equation 7. The intermediate compound is decomposed to alkyl ester (biodiesel) and unstable diglycerides anion (equation $8)$. The unstable diglycerides anion takes the proton ion from the protonated catalyst forming diglyceride and base catalyst (equation 9). The previous mechanism is repeated with the formed diglyceride to produce biodiesel and monoglyceride and is eventually repeated with the formed monoglyceride to produce glycerol and biodiesel.

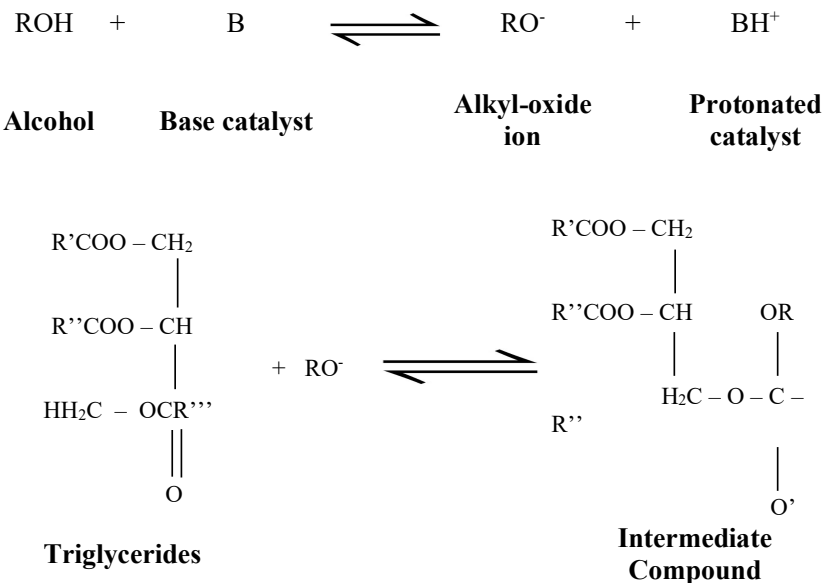

(6)

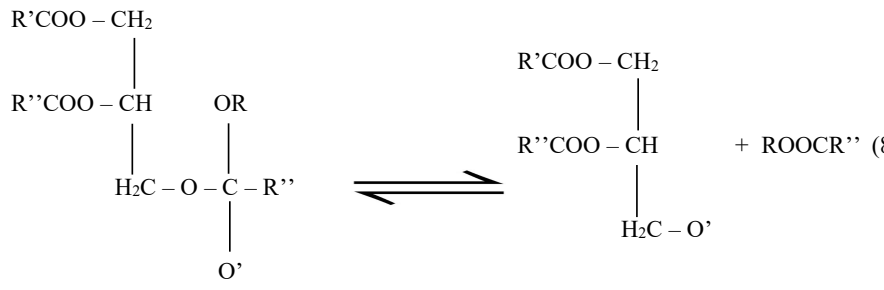

Intermediate Compound

Diglyceride
Anion

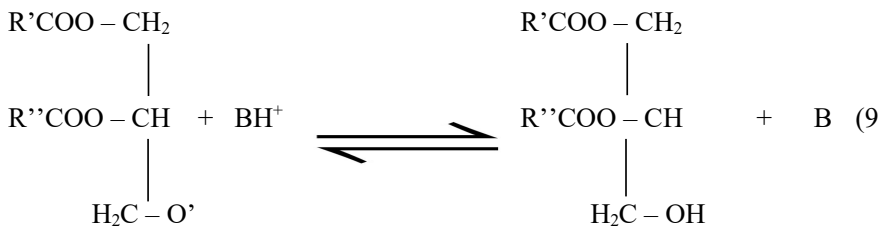

Diglyceride Anion

Diglycerides

\subsection{Acid catalyst transesterification}

In the acid transesterification process, a glyceride reacts with an alcohol in the presence of a homogenous acid catalyst such as sulfuric acid or hydrochloric acid forming fatty acid alkyl esters (biodiesel) and a glycerol ${ }^{[20]}$. Acid transesterification is neither common nor preferable in commercial or industrial plants as it is slower than base transesterification, furthermore, it needs more catalyst weight and intense temperature ${ }^{[88]}$.

Acids such as sulfuric acid $\left(\mathrm{H}_{2} \mathrm{SO}_{4}\right)$ and hydrochloric acid $(\mathrm{HCl})$ cause metal corrosion that destroys the metallic equipment and promotes metal oxide formation. Therefore, the utilization of acid catalyst requires more purification and neutralization steps ${ }^{[89]}$. Acid transesterification is extremely sensitive to water as water diluted the concentration of acid catalyst leading to the biodiesel yield depression ${ }^{[90]}$. Acid transesterification is not applied in commercial or industrial plants because of its slowness, large catalyst quantities, and high temperatures ${ }^{[20]}$. The reaction may occur at catalyst percentage $1 \%$ reaches up to $5 \%$ and at temperature above $100{ }^{\circ} \mathrm{C}$ to complete conversion.

Acid transesterification is highly sensitive to water as water hydrolyzes the triglycerides to diglycerides and FFA which lower the biodiesel yield ${ }^{[89]}$. The advantage of acid transesterification is its insensitivity to the free fatty acid so it can be occurred at higher free fatty acid content, higher than $1 \%{ }^{[00]}$. Goff et a ${ }^{[92]}$ stated that acid transesterification of used cooking oil would need reaction conditions: methanol to oil ratio is 50 , sulfuric acid is $3.5 \%$ at temperature of 70 ${ }^{\circ} \mathrm{C}$. Stamenkovic et al. ${ }^{[93]}$ used two different alcohols in acid-catalyzed transesterification and compared the results as in table 3 . 
Table 3. comparison between methanol and ethanol in acid catalyzed transesterification.

\begin{tabular}{|c|c|c|c|c|c|}
\hline Alcohol & Molar ratio & Catalyst & $\begin{array}{c}\text { Catalyst } \\
\text { wt.\% }\end{array}$ & $\begin{array}{c}\text { Time } \\
\text { (hr.) }\end{array}$ & $\begin{array}{c}\text { Yield } \\
\%\end{array}$ \\
\cline { 1 - 3 } Methanol & $3.6: 1$ & \multirow{2}{*}{$\begin{array}{c}\text { Sulfuric } \\
\text { acid }\end{array}$} & 0.1 & 40 & 79.3 \\
\cline { 1 - 3 } \cline { 5 - 6 } Ethanol & $3.6: 1$ & & 0.4 & 40 & 66.9 \\
\hline
\end{tabular}

Michael et al. ${ }^{[92]}$ evaluated the acid transesterification of soybean oil using sulfuric, hydrochloric, formic, acetic, and nitric acids at different loading rates; they found out that the sulfuric acid catalyst was the most effective and efficient. The result revealed that at $100{ }^{\circ} \mathrm{C}$ reaction temperature, $99 \%$ conversion of triglycerides in soybean oil could be completed in $8 \mathrm{~h}$ when 0.5 wt. $\%$ of $\mathrm{H}_{2} \mathrm{SO}_{4}$ catalyst and 9:1 methanol to oil ratio were used. Freedman et al ${ }^{[91]}$ demonstrated that the best reaction conditions of the soybean oil acid transesterification occurred at the following conditions: methanol to oil ratio $30: 1,1$ wt. \% of sulfuric acid at a temperature of $65^{\circ} \mathrm{C}$ in $69 \mathrm{~h}$ of reaction time. The biodiesel yield was $90 \%$.

Bhatti et al. ${ }^{[94]}$ applied the acid transesterification on waste tallow (chicken fat) by using $\mathrm{H}_{2} \mathrm{SO}_{4}$. The best conditions were at a catalyst concentration of $1.25 \mathrm{wt}$. $\%$, a reaction time of $24 \mathrm{~h}$, methanol to oil molar ratio 30:1, and a temperature of $50{ }^{\circ} \mathrm{C}$. The biodiesel yield was $99 \%\left[{ }^{[94]}\right.$. H. A. Farag et al. ${ }^{[95]}$ studied the factors impacting the production of biodiesel from an oil mixture composed of $50 \%$ sunflower and $50 \%$ soybean oil using sulfuric acid as the catalyst. They found out that the optimum reaction conditions for the best conversion of $96.6 \%$, were 6:1 molar ratio of methanol to oil, $60{ }^{\circ} \mathrm{C}$ reaction temperature, and a $\mathrm{H}_{2} \mathrm{SO}_{4}$ of $2.5 \mathrm{wt}$ \% in a time of $180 \mathrm{~min}$. N. Saravanan et al. ${ }^{[96]}$ produced biodiesel through acid catalyst transesterification by using butanol as alcohol instead of methanol. The best process conditions that gave a yield of $95.4 \%$ were 6 vol. $\%$ of sulfuric acid with $150 \%$ excess butanol in a reaction time of 5 hours. On the other hand, using methanol at the same conditions gave a biodiesel yield of $80 \%$.

C. Carlucci et al. ${ }^{[97]}$ used sulfated titanium $\left(\mathrm{TiO}_{2} / \mathrm{SO}_{4}\right)$ as a catalyst instead of a strong acid in the acid transesterification of soybean and castor oils. The maximum yield at $120{ }^{\circ} \mathrm{C}$ in $60 \mathrm{~min}$ was $40 \%$. Jr. Soriano et al. ${ }^{[98]}$ studied the transesterification of canola oil to produce biodiesel via homogeneous Lewis acid $\left(\mathrm{AlCl}_{3}\right.$ and $\left.\mathrm{ZnCl}_{2}\right)$ as a catalyst and tetrahydrofuran (THF) as a solvent. The variable conditions were the reaction time of $6,18,24 \mathrm{~h}$, the methanol to oil molar ratio of $6,12,24,42$ and 60 , the reaction temperature of 75 and $110{ }^{\circ} \mathrm{C}$, and the tetrahydrofuran (THF) to methanol mass ratio of 1:1. The catalyst amount was constant at 5 wt. \% based on the weight of oil. They concluded that $\mathrm{AlCl}_{3}$ was more active compared to $\mathrm{ZnCl}_{2}$ due to its higher acidity. Additionally, the best conditions with $\mathrm{AlCl}_{3}$ that achieved a conversion of $98 \%$ were $24: 1$ molar ratio at $110{ }^{\circ} \mathrm{C}$ and $18 \mathrm{~h}$ with $\mathrm{THF}$ as co-solvent. Acid catalysts are rarely investigated because the stronger activity of base catalysts achieves mild reaction conditions, less corrosion, lower methanol amount, shorter reaction time, higher biodiesel yield and, lower cost. Consequently, acid transesterification in comparison with base transesterification is not preferable in the biodiesel industry ${ }^{[99,100]}$.

\subsection{Heterogeneous catalyst transesterification}

In the heterogeneous transesterification reaction, a glyceride reacts with an alcohol in the presence of a heterogeneous catalyst forming fatty acid alkyl esters (biodiesel) and a glycerol. The common heterogeneous catalysts used in transesterification reaction are the oxides of base supported on a large surface area such as calcium oxide $(\mathrm{CaO})$, magnesium oxide $(\mathrm{MgO})$ and titanium dioxide $\left(\mathrm{TiO}_{2}\right)$. Calcium oxide is the preferable heterogeneous catalyst because of its strong activity, long lifetime, achieving moderate condition, afford severe conditions and it is not consumed in reaction ${ }^{[101,102]}$.

Heterogeneous catalyst transesterification is more economical than acid transesterification as catalyst can be recycled and reused in addition reaction time is short, no side reaction such as saponification and hydrolysis reactions and washing with distilled water is not required ${ }^{[103]}$. Guo et al. ${ }^{[104]}$ concluded that heterogonous catalyst achieved yield is $95 \%$ with reaction conditions: methanol to oil ratio is 7.5 , sodium silicate as a catalyst is $3 \%$ at temperature $60{ }^{\circ} \mathrm{C}$, time is 60 minutes and the mixing rate is $250 \mathrm{rpm}$.
The disadvantage of heterogeneous catalyst is that a co-solvent must be added to ensure mass transfer between reactants ${ }^{[105]}$. The advantages of heterogeneous catalyst are the elimination of soap formation, short reaction time, no existence of side reactions such as saponification reaction. Furthermore, heterogeneous transesterification occurs at mild reaction conditions of temperature, pressure and mixing rate ${ }^{[103]}$. M. Zabeti et al. ${ }^{[106]}$ investigated many heterogeneous catalysts in the transesterification reaction. They found that calcium oxide owned an extremely basic strength and less environmental effects due to its faint solubility in methanol. Magnesium oxide had the weakest basic strength and solubility in methanol among group II oxides. Zirconium oxide, titanium oxide, and zinc oxide are among the transition metal oxides that had substantial attention for biodiesel production due to their high acidity properties. These catalysts experienced good catalytic activities and good stability when used to catalyze esterification and transesterification simultaneously. However, they had not been used in the industrial production process, mainly because of the expensive catalyst cost and difficulty in filtering the small catalyst particles.

Ngamcharussrivichai et al. ${ }^{[107]}$ investigated $\mathrm{Ca}$ and $\mathrm{Zn}$ mixed oxides $(\mathrm{CaO} . \mathrm{ZnO})$ catalyst for the transesterification reaction. The catalyst was prepared by a conventional co-precipitation method of the corresponding mixed metal nitrate solution in the presence of a soluble carbonate salt. The yield achieved was $95 \%$ at $60{ }^{\circ} \mathrm{C}$, catalyst amount of $10 \mathrm{wt} . \%$, methanol to oil molar ratio $30: 1$, and a reaction time of $3 \mathrm{~h}$. They indicated that the mixed oxides owed relatively small particle sizes and enormous surface areas, compared to pure $\mathrm{CaO}$ and $\mathrm{ZnO}$. The new catalyst $(\mathrm{CaO} . \mathrm{ZnO})$ could be reused up to 3 times with maintaining the biodiesel content more than $90 \%$. F. Guo et al. ${ }^{[104]}$ concluded that the heterogonous catalyst sodium silicate achieved a biodiesel yield of $95 \%$ with the following reaction conditions: methanol to oil ratio 7.5:1, catalyst concentration 3 wt. $\%$ at a temperature of $60{ }^{\circ} \mathrm{C}$ in 60 minutes. M. Granados et al. ${ }^{[108]}$ used calcium oxide as a solid base catalyst in the transesterification of sunflower oil. They revealed that $94 \%$ conversion was achieved after 100 min of reaction time, at $60^{\circ} \mathrm{C}$ with methanol to oil molar ratio of $13: 1$ and catalyst amount of $3 \mathrm{wt}$. \%.

W. Xie and T. Wang ${ }^{[109]}$ studied soybean oil transesterification with tungsten oxide and stannic oxide $\left(\mathrm{WO}_{3} / \mathrm{SnO}_{2}\right)$ as a heterogeneous acid catalyst. The catalyst was prepared by impregnation method and calcination temperature reached to $1173 \mathrm{~K}$. The best yield was $80 \%$ at $110{ }^{\circ} \mathrm{C}$ with the percentage of catalyst $5 \mathrm{wt}$. \% and methanol to oil molar ratio 30:1. The prepared catalyst was insensitive to water and could be reused four times with no deactivation. Jerry 1. Solis et al ${ }^{[110]}$ investigated the effect of stannic oxide $\left(\mathrm{SnO}_{2}\right)$ with calcium oxide $(\mathrm{CaO})$ catalyst on transesterification reaction. The feedstock used contained a high percentage of FFAs. They prepared many different mass ratios between calcium oxide and stannic oxide; therefore, they found that the maximum biodiesel yield $99.7 \%$ obtained at $60{ }^{\circ} \mathrm{C}$ with the percentage of catalyst $6 \mathrm{wt} . \%$, methanol to oil molar ratio $10: 1$ and the best ratio between $\mathrm{SnO}_{2} / \mathrm{CaO}$ was 3:7 mass ratio.

\subsection{Supercritical methanol transesterification}

Supercritical methanol transesterification is a process which includes production of biodiesel from triglyceride by using alcohol at high temperature and pressure (under supercritical conditions) in absence of catalyst. The advantage of this process is the absence of catalyst, high yield, insensitivity to high free fatty acids and water content, no side reaction, various resources of feedstocks, less transesterification steps and biodiesel yield is more than $96 \%{ }^{[21]}$. Supercritical methanol transesterification does not require a pretreatment steps as this method of transesterification is insensitive to FFA and water in addition the absence of catalyst prevents soap formation so transesterification can be done directly to any feedstock with any specification ${ }^{[56,111]}$.

The disadvantage of the supercritical methanol transesterification is the severe operating conditions as the reaction temperature and pressure are extremely high that may reach to $350{ }^{\circ} \mathrm{C}$ and $20 \mathrm{MPa}$. Furthermore, an enormous amount of alcohol is required to complete the reaction ${ }^{[113]}$. Consequently, this process is not common due to its high production cost.

Kusdiana and $\mathrm{Saka}^{[45]}$ reported that the supercritical methanol transesterification method was very useful in the case of great FFAs content and water in the feedstock. They investigated the reaction conditions between $200^{\circ} \mathrm{C}$ to $500^{\circ} \mathrm{C}$ with different molar ratios of methanol to rapeseed oil. The highest biodiesel yield of $95 \%$ was achieved at a reaction temperature of $350^{\circ} \mathrm{C}$ with the 
molar ratio of methanol to rapeseed oil of $42: 1$. S. Karki et al. ${ }^{[114]}$ used methanol and ethanol in the supercritical transesterification. The experiments were done at temperatures of 250,270 and $290{ }^{\circ} \mathrm{C}$, a reaction time of 0 to $60 \mathrm{~min}$ and oil to alcohol molar ratios of 1:6, 1:12 and 1:18 for both alcohols. The conversion improved with increasing the reaction temperature and time. The conversion achieved was nearly $96 \%$ at $290{ }^{\circ} \mathrm{C}$, in a reaction time of $60 \mathrm{~min}$, and the oil to alcohol molar ratio of 1:18 for both alcohols. Additionally, the glycerol amount was less than 5 wt. $\%$.

O. Farobie et Y. Matsumura ${ }^{[115]}$ invented a novel spiral reactor to produce biodiesel by the supercritical methanol transesterification. The spiral reactor was used as a heat exchanger in order to recover the heat and conserve energy. The transesterification reaction carried out at $270-400{ }^{\circ} \mathrm{C}$, a pressure of $20 \mathrm{MPa}$, oil to methanol molar ratio of 1:40, and a reaction time of 3-30 min. The optimum conditions that achieved a complete conversion of biodiesel (100 wt. \%) were obtained in a short reaction time of $10 \mathrm{~min}$ and methanol to oil molar ratio of $40: 1$ at $350^{\circ} \mathrm{C}$ under a reactor pressure of $20 \mathrm{MPa}$. They concluded that the spiral reactor produced biodiesel yield more than that the biodiesel produced in a batch reactor at the same reaction conditions.

Jian-Zhong Yin et al. ${ }^{[16]}$ produced biodiesel from soybean oil using methanol under supercritical and subcritical conditions. The best operating parameters of the supercritical conditions that achieved a yield of $98 \%$ when the molar ratio of methanol to oil was $42: 1$, the pressure was $32 \mathrm{MPa}$ and the reaction temperature ranged from $260{ }^{\circ} \mathrm{C}$ to $350^{\circ} \mathrm{C}$ within 20 minutes. In this work, they used a novel idea by adding $\mathrm{KOH}$ to the reactants in order to decrease the operating temperature and pressure. The best operating parameters of the subcritical conditions that achieved a yield of $98 \%$ when the molar ratio of methanol to oil was $24: 1$, at a temperature of $160{ }^{\circ} \mathrm{C}$, and the pressure was $10 \mathrm{MPa}$ within 20 minutes using $0.1 \%$ wt. $\mathrm{KOH}$. Chao-Yi Wei et $\mathrm{a}^{[117]}$ used supercritical methanol, carbon dioxide, and acetic acid to produce biodiesel from soybean oil. The aim of using carbon dioxide was to lessen the reaction temperature and rise the solubility of fats in the reaction medium. Acetic acid was added to reduce the glycerol byproduct and raise the hydrolysis of fatty acids. The optimal reaction conditions that achieved a biodiesel yield of $97.83 \%$ were a temperature of 280 ${ }^{\circ} \mathrm{C}$, a methanol-to-oil ratio of 60 , acetic acid to oil ratio of 3:1, a time of $90 \mathrm{~min}$ and a reaction pressure of $20 \mathrm{MPa}$. The glycerol byproduct was less than 2 wt. $\%$.

Non-catalyzed supercritical methanol transesterification process can be done with reaction conditions: methanol to oil ratio is $42: 1$, at temperature $300{ }^{\circ} \mathrm{C}$ to $400{ }^{\circ} \mathrm{C}$, pressure is at least $80 \mathrm{bar}$, time is 12 to $50 \mathrm{~min}^{[56]}$. Imahara et al. ${ }^{[118]}$ investigated that this method is very useful in case of high FFAs and water in feedstock while Banerjee et al. ${ }^{[19]}$ concluded that the transesterification of used cooking by this technology produced biodiesel with $99.8 \%$ purity and by product glycerol with $96.4 \%$ purity. The disadvantage of non-catalyzed supercritical methanol transesterification process is high operating cost as temperature and pressure are extremely high and high amount of alcohol is required ${ }^{[111]}$. Kusdiana et al. ${ }^{[120]}$ compared between catalytic method and supercritical methanol method as in table 4 .

Table 4: Comparison between catalytic and Supercritical alcohol transesterification

\begin{tabular}{|l|l|c|}
\hline Variable & Catalytic transesterification & $\begin{array}{c}\text { Supercritical } \\
\text { alcohol }\end{array}$ \\
\hline Alcohol & Methanol & Methanol \\
\hline Time (min) & $60-360$ & $7-15$ \\
\hline Temperature $\left({ }^{\circ} \mathbf{C}\right)$ & $30-65$ & $340-385$ \\
\hline Pressure (Mpa) & 0.1 & $10-25$ \\
\hline Catalyst & $\mathrm{KOH} / \mathrm{H}_{2} \mathrm{SO}_{4}$ & None \\
\hline Yield \% & 96 & 98 \\
\hline Removal for purification & Methanol, glycerol, catalyst, soap & Methanol \\
\hline
\end{tabular}

\subsection{Enzymatic transesterification}

Enzymatic transesterification is the production of biodiesel from triglyceride and FFAs in the presence of lipases enzymes as a catalyst. The enzymatic process is a clean and environment friendly process for biodiesel production. It can simultaneously convert both FFA and triglyceride into biodiesel [117, 118]. Enzymatic transesterification is characterized by low operating temperature $\left(35-45^{\circ} \mathrm{C}\right)$, no glycerol formation, elimination of side reaction or by-products, insensitivity to the presence of FFAs or water in feedstock, high yield, and catalyst can be reused ${ }^{[102,121]}$

The disadvantage of enzymatic transesterification is the high cost of catalyst, slow reaction rate, lower in activity, and sensitivity of catalyst to alcohol as methanol deactivates the catalyst so biodiesel yield becomes lower ${ }^{[81,122]}$. Unfortunately, these problems are still existing in academic journals and mass media

\section{BIODIESEL PRODUCTION STEPS}

\subsection{Solid Particles Impurities removal}

The solid particles in feedstock such as gravel, sand, bones, dirt, gum and insoluble particles should be removed as it obstruct the proper mixing of reactants. Consequently, the feedstock should be passed through a filter with meshes size of 250 micrometer to guarantee the perfect removal of these impurities $^{[123]}$.

\subsection{Water drying}

The filtered feedstock is heated to above $100{ }^{\circ} \mathrm{C}$ so as to get rid of water as it causes decomposition of triglyceride to diglycerides or monoglycerides and free fatty acid and hence soap formation so it destroy the transesterification reaction ${ }^{[9]}$. Utilization of anhydrous of alcohol and catalyst in a process is necessary and the maximum water content shouldn't be more than $0.3 \mathrm{wt} . \%^{[124]}$. Feedstock after water drying must be left in air so as to be cooled to the surrounding environmental temperature before transesterification reaction ${ }^{[125]}$.

\subsection{Transesterification reaction}

The transesterification reaction is the main reaction that produces fatty acid alkyl ester (biodiesel); the other main product is glycerol, which have a density higher than biodiesel density. Firstly, $\mathrm{KOH}$ was added slowly and carefully to the methanol agitated in the mixer to ensure a complete dissolving. A magnetic stirrer was used to achieve better mixing of alcohol and catalyst. The mixing speed of methanol with catalyst was $250 \mathrm{rpm}$ and should not be above this range so as not to volatilize methanol. Secondly, the feedstock was heated to $60{ }^{\circ} \mathrm{C}$, which is the temperature for the reaction. The prepared mixture of $\mathrm{KOH}$ and methanol was decanted into the flask with the hot feedstock and mixed for $2 \mathrm{hr}$. Finally, the mixture settled in a separating funnel for fours hours to complete the phase separation. Two layers produced; the top layer was the crude biodiesel with a light yellow color. The bottom layer was a mixture of glycerol and catalyst and its color was dark brown.

\subsection{Biodiesel separation}

The first purification step of biodiesel is separation of biodiesel and glycerol by the difference in their densities as the biodiesel density is around $0.88 \mathrm{gm} / \mathrm{cm}^{3}$ while density of glycerol is around $1.05 \mathrm{gm} / \mathrm{cm}^{3}{ }^{[90,126]}$. The lower layer is glycerol and upper layer is biodiesel.

\subsection{Water washing}

The second step of biodiesel purification is the water washing of produced biodiesel with warm distilled water at ambient temperature. The aim of water washing is to remove salts and soap formed during transesterification reaction $^{[126]}$. The washing step is repeated until the biodiesel layer become clear and water layer become transparent ${ }^{[126]}$

\section{BIODIESEL PROPERTIES}

Biodiesel has to be identical to the international biodiesel standard specifications provided by American standard for testing materials (ASTM) or EN14214 in the European Union for alternative fuels. Biodiesel must be free from methanol, catalyst, water, glycerol and solid contaminations to achieve high purity $^{[127,128]}$.

The following specifications are for the biodiesel according to American standard test method (ASTM) ${ }^{[77,128]}$. 


\subsection{Appearance and odor}

Biodiesel color varies between yellow, golden and dark brown. Biodiesel is odorless except when made from used cooking oil or animal fat.

\subsection{Density and API gravity}

Density is an important fuel property because fuel pump and injection systems must receive a precise amount of fuel to provide a proper combustion. Therefore, fuel density is the main property that influences the amount of mass injected in the internal combustion room. The standard density as per ASTM D-6751 ranges from 0.86 to $0.9 \mathrm{~g} / \mathrm{cm}^{3}$ at $15{ }^{\circ} \mathrm{C}$. The API gravity is an indication of quality of diesel. It is measured according to American petroleum institute standards by equation $10^{[129]}$.

$$
\text { API gravity }=\left(\frac{141.5}{S P . G R}\right)-131.5
$$

\subsection{Acid Value}

Acid value is the milligrams of potassium hydroxide required to neutralize one gram of oil. The acid number is an indication of the amount of acid and water in biodiesel. High acid number means that the biodiesel have high percentage of water and free fatty acid, so it need more processing steps to remove water and acids. The acid number is measured according to ASTM-D664.

\subsection{FFA content}

The FFAs \% is the half of acid number. Therefore, the FFAs content is an indication of the amount of acid and water in biodiesel like the acid number.

\subsection{Viscosity}

Fuel viscosity is a measure of resistance for its free flow showing strong influence on fuel injection and consequent spray formation processes such as atomization, spray growth, etc.

\subsection{Pour point and cloud point}

The pour point of a liquid is the lowest temperature at which liquid can flow when it is cooled. The pour point is measured according to ASTM-D97. The cloud point is the temperature at which the solid crystals or wax are formed in cloudy color when it is cooled ${ }^{[130]}$. The cloud point is measured according to ASTM-D2500.

\subsection{Water content}

Water is an undesirable product in biodiesel because of the destructive effect of water on the final yield quantities and properties. Water can promote microbial growth, leads to engine corrosion, participates in the formation of emulsions, causes hydrolysis, lowers the calorific value of biodiesel, and causes a longer ignition delay in the pistons of the diesel engine. The standard specifications (ASTM-6751) limits the maximum allowable content of water in biodiesel fuel to $0.05 \%$ wt. Industrially, water is removed from biodiesel using distillation under vacuum $(0.05$ bar $)$ at temperatures between $30-40{ }^{\circ} \mathrm{C}^{[131]}$.

\subsection{Ash content}

Ash is an inorganic residue that remains after combustion. Ash content of biodiesel should not exceed the standard limits as the high percentage of ash causes air pollution, plugging in fuel filters and engine due to the ash particles accumulation. There are three forms of ash forming materials almost found in biodiesel that are soluble metallic solids, abrasive solids, and un-removed catalysts ${ }^{[9,130]}$. The ash content is determined according to ASTM-482. Table 5 compares between the standard specification of ASTM and EN-14214.

\subsection{Heating value (Calorific value)}

Calorific value is a measure of heating power and is dependent upon the composition of the biodiesel. The heating value refers to the amount of energy released when a known mass of biodiesel is completely combusted under specified conditions. The calorific value of biodiesel is in the range of 35 $40 \mathrm{MJ} / \mathrm{kg}$ compared to $45 \mathrm{MJ} / \mathrm{kg}$ for petroleum diesel due to the chemically bound oxygen in biodiesel that lowers heating values by about $10 \%$. Table 5 shows the standard values needed for biodiesel to be considered a standard fuel ${ }^{[77,127,128]}$.

\subsection{Aniline Point}

It is the temperature at which two equal immiscible liquids of aniline $\left(\mathrm{C}_{6} \mathrm{H}_{5} \mathrm{NH}_{2}\right)$ and the oil become completely miscible and one layer formed. Aniline point is an indication of aromatic content in sample. The fuel with low aniline point means that the percentage of aromatics content is high and paraffins content is low. The greater the aniline point the lower the aromatic content. The aniline point is measured according to ASTM-D611.

\subsection{Cetane Number}

Cetane number is the time between the injection start and first ignition. It is an indication of the combustion quality of diesel fuel during compression ignition. It is similar to the octane number in gasoline. Cetane number is an important factor in determining the chemical compound in biodiesel. High cetane number leads to shorter ignition retard, lower nitrogen oxides emissions, lower carbon monoxides emissions, lower noise and stable engine operation so higher fuel quality. Low cetane number fuels can be improved by using additives which increase cetane number to be within the standard limits ${ }^{[130]}$. The Cetane number is measured according to ASTM-D613.

\subsection{Flash point}

The flash point is the temperature at which the liquid vapors ignite under normal pressure ${ }^{[130]}$. The flash point is measured according to ASTM-D93.

Table 5: Biodiesel ASTM and EN-14214 standard specifications.

\begin{tabular}{|c|c|c|c|}
\hline Property & Units & ASTM limits & EN- limits \\
\hline Density & $\mathrm{g} / \mathrm{cm}^{3}$ & $0.85-0.9$ & $0.86-0.9$ \\
\hline Cetane number & -- & $47 \mathrm{~min}$ & $51 \mathrm{~min}$ \\
\hline Kinematic Viscosity & C.st & $1.9-6$ & $3.5-5$ \\
\hline Free fatty acid & $\%$ & $0.42 \max$ & $0.25 \max$ \\
\hline Acid number & $\mathrm{mg} \mathrm{KOH} / \mathrm{g}$ & $0.8 \max$ & $0.5 \max$ \\
\hline Flash point & ${ }^{\circ} \mathrm{C}$ & $130-191$ & $120 \mathrm{~min}$ \\
\hline Aniline point & ${ }^{\circ} \mathrm{C}$ & $96-97$ & -- \\
\hline Cloud point & ${ }^{\circ} \mathrm{C}$ & -3 to 12 & -- \\
\hline Pour point & ${ }^{\circ} \mathrm{C}$ & -15 to 10 & -- \\
\hline Calorific value & $\mathrm{MJ} / \mathrm{kg}$ & $35-40$ & -- \\
\hline Ash content & $\%$ & $0.02 \max$ & $0.02 \max$ \\
\hline
\end{tabular}

\section{BIODIESEL APPLICATIONS}

Biodiesel can be used in a pure form or as a mixture with petrodiesel at any concentration. B100 is a pure biodiesel without any amount of petrodiesel while B20 is a blend containing $20 \%$ biodiesel, $80 \%$ petrodiesel. Biodiesel as fuel has many advantages, as it is a clean, cheap, renewable fuel.

\subsection{Generating electricity}

Biodiesel can be utilized as a fuel in generators that produce electricity. With B100, generators can eliminate the accompanying products such as smog, ozone, carbon, and sulfur emissions. Therefore, using biodiesel as a fuel for generators in domestic areas such as schools, hospitals, and the general public will reduce the harmful emissions such as carbon monoxide and particulate matter ${ }^{[132]}$. In 2001, UC Riverside installed a 6-megawatt backup power system that used biodiesel as a fuel. These generators allow companies prevent the destruction blackouts of processes at the expense of high pollution and emission rates. 


\subsection{Railway usage}

The separate locomotive provides the motive power for a train. The most known types of locomotive are diesel and electrical type. Biodiesel can be used directly in locomotive for either passengers or cargo trains. There are many countries uses biodiesel as fuel in trains such as the UK, the USA, and India. British railways ran the UK's first biodiesel train, using a mixture fuel of $80 \%$ petro-diesel and $20 \%$ biodiesel.

In 2007 , the British royal train made its first journey by $100 \%$ biodiesel fuel $^{[133}$ ${ }^{134]}$. In the USA, they began using biodiesel to run the trains in 2007 . The Indian railway minister announced that $5 \%$ of biodiesel would be used in Indian railways' diesel engines ${ }^{[135]}$.

\subsection{Heating home}

Heating oil is identical to diesel fuel. Biodiesel can be used as a heating oil in residential and industrial buildings. A 20\% of biodiesel blend (B20) may be used without any modification; higher blends may affect rubber seals and gaskets in older equipment. Using biodiesel as a heating oil will reduce the emissions of both sulfur dioxide and nitrogen oxides and will clean out fuel pipes, which can improve heating efficiency filters ${ }^{[136]}$.

\subsection{Cooking}

Kerosene is the most known fuel used for stoves and non-wick lanterns. However, biodiesel works as a great substitute for kerosene ${ }^{[136]}$. Using biodiesel as a fuel for stoves is safer than kerosene and liquefied petroleum gases because of the high flash point of biodiesel.

\subsection{Diesel vehicles}

Biodiesel works in the engine in the same way as standard diesel. Almost all diesel vehicles are able to run on biodiesel without any engine modification. It is recommended that older engines that still have some rubber components in the fuel system replace these parts with a synthetic material, as the solvent properties of biodiesel could cause wear to these parts. Big manufacturers such as BMW, Audi, and Mercedes approved the use of biodiesel up to a maximum of $20 \%(\mathrm{~B} 20)^{[137]}$.

\subsection{Boilers}

Biodiesel can be used as a fuel for boilers that generate steam for industrial processes. Emissions testing shows that the use of B20 in a boiler can reduce particulate matter emissions by $20 \%$, and can decrease nitrogen oxides emissions by $20 \%$. Using biodiesel as a fuel for boilers instead of fossil fuel helps to burn more efficiently and reduce operating costs $[138,139]$.

\section{CONCLUSION}

Biodiesel is a promising and more attractive fuel for diesel engines owing to its renewable nature and environmental benefits. The key issue to take into consideration is the higher price of biofuels than fossil fuel. Using low-quality feedstocks - which do not compete with food supply and land for food cultivation such as non-edible oils and animal fats- is considered an effective way of reducing the biodiesel production costs

The present work shows the different treatment processes to reduce the high FFAs in the feedstock. The glycerolysis treatment has many merits over acid esterification since it is faster, lower toxic, and cheaper. The researches in glycerolysis treatment are limited and needs more investigation and discussion.

The paper also shows that feedstocks of biodiesel varies between edible oil such as the oil of sunflower, soybean and coconut or non-edible oil such as the oil of Jatropha, jojoba and used cooking oil. Biodiesel is produced from vegetable oil through transesterification reaction at which the organic group (alkyl) of an alcohol is substituted with the organic group of a triglyceride producing fatty acid alkyl ester (FAME) and glycerol. The production of biodiesel is simple process does not need a license or a complicated technology.

There are four types of the transesterification processes, acid-catalyzed transesterification, alkaline catalyzed transesterification, enzyme catalyzed transesterification and non catalyzed supercritical methanol. The alkaline catalyzed transesterification method is the most common process to be used as it is the fastest reaction, the highest yield, the mildest reaction condition, the lowest cost, corrosive, and toxicity.

Eventually, the amount of consumed diesel in the world is massive and has a reverse effect on the economy and environment. Therefore, accelerate in changing to the utilization of biodiesel will have a great effect on the environment, vehicle engines, independency on crude oil, investment and economy as it will create jobs.

\section{REFERENCES}

1. Kirubakaran, M. and V.A.M. Selvan, A comprehensive review of low cost biodiesel production from waste chicken fat. Renewable and sustainable energy reviews, 82: p. 390-401(2018.)

2. Vonortas, A. and N. Papayannakos, Comparative analysis of biodiesel versus green diesel. Wiley Interdisciplinary Reviews: Energy and Environment, 3(1): p. 3-23(2014.)

3. Verma, P. and M. Sharma, Review of process parameters for biodiesel production from different feedstocks. Renewable and sustainable energy reviews, 62: p. 1063-71(2016.)

4. Alptekin, E., M. Canakci, and H. Sanli. Methyl ester production from chicken fat with high FFA. in World Renewable Energy Congress-Sweden, 8-13 May; 2011; Linköping; Sweden. 2011. Linköping University Electronic Press.

5. Jansri, S., et al., Kinetics of methyl ester production from mixed crude palm oil by using acid-alkali catalyst. Fuel processing technology, 92(8): p. 1543 8(2011.)

6. Latif, M.A.A., et al. Nanostructure and oxidation properties investigation of engine using Jatropha biodiesel as engine fuel. in MATEC Web of Conferences. 2017. EDP Sciences.

7. Tziourtzioumis, D.N. and A.M. Stamatelos, Investigation of the effect of biodiesel blends on the performance of a fuel additive-assisted diesel filter system. International Journal of Engine Research, 15(4): p. 406-20(2014.)

8. Rouhany, M. and H. Montgomery, Global Biodiesel Production: The State of the Art and Impact on Climate Change, in Biodiesel. 2019, Springer. p. 1 14.

9. Mishra, V.K. and R. Goswami, A review of production, properties and advantages of biodiesel. Biofuels, 9(2): p. 273-89(2018.)

10. Živković, S. and M. Veljković, Environmental impacts the of production and use of biodiesel. Environmental Science and Pollution Research, 25(1): p. 191-9(2018.)

11. Giakoumis, E.G., Analysis of 22 vegetable oils'physico-chemical properties and fatty acid composition on a statistical basis, and correlation with the degree of unsaturation. Renewable energy, 126: p. 403-19(2018.)

12. El-Gharbawy, A.S.A.A., PRODUCTION OF BIODIESEL FROM NON EDIBLE VEGETABLE OIL. 2016

13. Azizian, H. and J.K. Kramer, A rapid method for the quantification of fatty acids in fats and oils with emphasis on trans fatty acids using Fourier transform near infrared spectroscopy (FT-NIR). Lipids, 40(8): p. 85567(2005.)

14. Balat, M., Potential alternatives to edible oils for biodiesel production-A review of current work. Energy conversion and management, 52(2): p. 147992(2011.)

15. Gui, M.M., K. Lee, and S. Bhatia, Feasibility of edible oil vs. non-edible oil vs. waste edible oil as biodiesel feedstock. Energy, 33(11): p. 164653(2008.)

16. Rincón, L., J. Jaramillo, and C. Cardona, Comparison of feedstocks and technologies for biodiesel production: An environmental and technoeconomic evaluation. Renewable Energy, 69: p. 479-87(2014.)

17. Ambat, I., V. Srivastava, and M. Sillanpää, Recent advancement in biodiesel production methodologies using various feedstock: A review. Renewable and sustainable energy reviews, 90: p. 356-69(2018.)

18. Demirbas, A., Comparison of transesterification methods for production of biodiesel from vegetable oils and fats. Energy conversion and management, 49(1): p. 125-30(2008.)

19. Leung, D.Y., X. Wu, and M. Leung, A review on biodiesel production using catalyzed transesterification. Applied energy, 87(4): p. 1083-95(2010.)

20. Likozar, B. and J. Levec, Transesterification of canola, palm, peanut, soybean and sunflower oil with methanol, ethanol, isopropanol, butanol and tert-butanol to biodiesel: Modelling of chemical equilibrium, reaction kinetics and mass transfer based on fatty acid composition. Applied Energy, 123: p. 108-20(2014.)

21. Demirbas, A., Biodiesel from waste cooking oil via base-catalytic and supercritical methanol transesterification. Energy conversion and management, 50(4): p. 923-7(2009.) 
22. Elgharbawy, A.S.A.A., cost analysis for biodiesel production from waste cooking oil plant in Egypt. International Journal of Smart Grid-ijSmartGrid, 1(1): p. 16-25(2017.)

23. Elgharbawy, A.S., et al., Glycerolysis treatment to enhance biodiesel production from low-quality feedstocks. Fuel, 284: p. 118970(2021.)

24. Ramadhas, A.S., S. Jayaraj, and C. Muraleedharan, Biodiesel production from high FFA rubber seed oil. Fuel, 84(4): p. 335-40(2005.)

25. Van Gerpen, J., Biodiesel processing and production. Fuel processing technology, 86(10): p. 1097-107(2005.)

26. Atadashi, I., et al., Production of biodiesel using high free fatty acid feedstocks. Renewable and sustainable energy reviews, 16(5): p. 327585(2012.)

27. Knothe, G., J.H. Van Gerpen, and J. Krahl, The biodiesel handbook. Vol. 1. 2005: AOCS press Champaign, IL.

28. Anderson, E., et al., Glycerin esterification of scum derived free fatty acids for biodiesel production. Bioresource technology, 200: p. 153-60(2016.)

29. Tan, H., A.A. Aziz, and M. Aroua, Glycerol production and its applications as a raw material: A review. Renewable and sustainable energy reviews, 27: p. 118-27(2013.)

30. Kombe, G.G., et al., Pre-treatment of high free fatty acids oils by chemical re-esterification for biodiesel production - a review. Advances in Chemical Engineering and Science, 2013(2013.)

31. Felizardo, P., et al., Study on the glycerolysis reaction of high free fatty acid oils for use as biodiesel feedstock. Fuel Processing Technology, 92(6): p. 1225-9(2011.)

32. Díaz, I., et al., Synthesis of MCM-41 materials functionalised with dialkylsilane groups and their catalytic activity in the esterification of glycerol with fatty acids. Applied Catalysis A: General, 242(1): p. 1619(2003.)

33. Sani, Y., W. Daud, and A. Abdul Aziz, Biodiesel feedstock and production technologies: Successes, challenges and prospects. Biodiesel-Feedstocks, Production, and Applications, 10: p. 52790(2012.)

34. Gebremariam, S. and J. Marchetti, Economics of biodiesel production. Energy Conversion and Management, 168: p. 74-84(2018.)

35. Gnanaprakasam, A., et al., Recent strategy of biodiesel production from waste cooking oil and process influencing parameters: a review. Journal of Energy, 2013(2013.)

36. Bhuiya, M., et al., Second generation biodiesel: potential alternative toedible oil-derived biodiesel. Energy Procedia, 61: p. 1969-72(2014.)

37. Pragya, N., K.K. Pandey, and P. Sahoo, A review on harvesting, oil extraction and biofuels production technologies from microalgae. Renewable and sustainable energy reviews, 24: p. 159-71(2013.)

38. Karmakar, A., S. Karmakar, and S. Mukherjee, Properties of various plants and animals feedstocks for biodiesel production. Bioresource technology, 101(19): p. 7201-10(2010.)

39. Riazi, M. and D. Chiaramonti, Biofuels production and processing technology. 2017: CRC Press.

40. Sumathi, S., S. Chai, and A. Mohamed, Utilization of oil palm as a source of renewable energy in Malaysia. Renewable and sustainable energy reviews, 12(9): p. 2404-21(2008.)

41. Demirbas, A., Importance of biodiesel as transportation fuel. Energy policy, 35(9): p. 4661-70(2007.)

42. Baskar, G. and R. Aiswarya, Trends in catalytic production of biodiesel from various feedstocks. Renewable and sustainable energy reviews, 57: p. 496504(2016.)

43. Demirbas, A., et al., Biodiesel production from non-edible plant oils. Energy Exploration \& Exploitation, 34(2): p. 290-318(2016.)

44. Banković-Ilić, I.B., O.S. Stamenković, and V.B. Veljković, Biodiesel production from non-edible plant oils. Renewable and sustainable energy reviews, 16(6): p. 3621-47(2012.)

45. Acquaye, A.A., et al., Biofuels and their potential to aid the UK towards achieving emissions reduction policy targets. Renewable and sustainable energy reviews, 16(7): p. 5414-22(2012.)

46. Thamsiriroj, T. and J. Murphy, The impact of the life cycle analysis methodology on whether biodiesel produced from residues can meet the $E U$ sustainability criteria for biofuel facilities constructed after 2017. Renewable Energy, 36(1): p. 50-63(2011.)

47. Akubude, V., K. Nwaigwe, and E. Dintwa, Production of biodiesel from microalgae via nanocatalyzed transesterification process: A review. Materials Science for Energy Technologies, 2(2): p. 216-25(2019.)

48. Khan, S., et al., Biodiesel production from algae to overcome the energy crisis. HAYATI Journal of Biosciences, 24(4): p. 163-7(2017.)

49. Milledge, J.J. and S. Heaven, A review of the harvesting of micro-algae for biofuel production. Reviews in Environmental Science and Bio/Technology, 12(2): p. 165-78(2013.)
50. Bhosle, B. and R. Subramanian, New approaches in deacidification of edible oils - a review. Journal of Food Engineering, 69(4): p. 481-94(2005.)

51. Hayyan, A., et al., Reduction of high content of free fatty acid in sludge palm oil via acid catalyst for biodiesel production. Fuel Processing Technology, 92(5): p. 920-4(2011.)

52. Chai, M., et al., Esterification pretreatment of free fatty acid in biodiesel production, from laboratory to industry. Fuel processing technology, 125: p. 106-13(2014.)

53. Kara, K., et al., Biodiesel production from waste fish oil with high free fatty acid content from Moroccan fish-processing industries. Egyptian Journal of Petroleum, 27(2): p. 249-55(2018.)

54. Sianipar, R.N.R., D. Ariyani, and I.F. Nata, Conversion of palm oil sludge to biodiesel using alum and $\mathrm{KOH}$ as catalysts. Sustainable Environment Research, 27(6): p. 291-5(2017.)

55. Marchetti, J. and A. Errazu, Esterification of free fatty acids using sulfuric acid as catalyst in the presence of triglycerides. Biomass and Bioenergy, 32(9): p. 892-5(2008.)

56. Thaiyasuit, P., K. Pianthong, and I. Worapun, Acid esterification-alkaline transesterification process for methyl ester production from crude rubber seed oil. Journal of oleo science, 61(2): p. 81-8(2012.)

57. Sadaf, S., et al., Biodiesel production from waste cooking oil: an efficient technique to convert waste into biodiesel. Sustainable Cities and Society, 41: p. 220-6(2018.)

58. García Martín, J.F., et al., Esterification of Free Fatty Acids with Glycerol within the Biodiesel Production Framework. Processes, 7(11): p. 832(2019.)

59. Fregolente, P.B.L., et al., Monoglycerides and diglycerides synthesis in a solvent-free system by lipase-catalyzed glycerolysis, in Biotechnology for Fuels and Chemicals. 2008, Springer. p. 285-92.

60. Sousa, L.L., I.L. Lucena, and F.A.N. Fernandes, Transesterification of castor oil: Effect of the acid value and neutralization of the oil with glycerol. Fuel Processing Technology, 91(2): p. 194-6(2010.)

61. Binhayeeding, N., S. Klomklao, and K. Sangkharak, Utilization of waste glycerol from biodiesel process as a substrate for mono-, di-, and triacylglycerol production. Energy Procedia, 138: p. 895-900(2017.)

62. Mostafa, N., A. Maher, and W. Abdelmoez, Production of mono-, di-, and triglycerides from waste fatty acids through esterification with glycerol. Advances in Bioscience and Biotechnology, 4(09): p. 900(2013.)

63. Hermida, L., A.Z. Abdullah, and A.R. Mohamed, Synthesis of monoglyceride through glycerol esterification with lauric acid over propyl sulfonic acid post-synthesis functionalized SBA-15 mesoporous catalyst. Chemical Engineering Journal, 174(2-3): p. 668-76(2011.)

64. Gole, V.L. and P.R. Gogate, Intensification of glycerolysis reaction of higher free fatty acid containing sustainable feedstock using microwave irradiation. Fuel processing technology, 118: p. 110-6(2014.)

65. Megawati, M., et al., The Kinetics of Calcium Oxide Catalyzed Esterification of Glycerol with Free Fatty Acids Using Pseudo-homogeneous Model Approach. Reaktor, 18(1): p. 1-6(

66. Kombe, G.G., et al., Low temperature glycerolysis as a high FFA pretreatment method for biodiesel production. Advances in Chemical Engineering and Science, 2013(2013.)

67. Chetpattananondh, P. and C. Tongurai, Synthesis of high purity monoglycerides from crude glycerol and palm stearin. Songklanakarin Journal of Science \& Technology, 30(4)(2008.)

68. Xiao, Y., G. Xiao, and A. Varma, A universal procedure for crude glycerol purification from different feedstocks in biodiesel production: experimental and simulation study. Industrial \& engineering chemistry research, 52(39): p. 14291-6(2013.)

69. Wan Isahak, W.N.R., et al., Recovery and purification of crude glycerol from vegetable oil transesterification. Separation \& Purification Reviews, 44(3): p. 250-67(2015.)

70. Rashid, U., et al., Production of sunflower oil methyl esters by optimized alkali-catalyzed methanolysis. Biomass and bioenergy, 32(12): p. 12025(2008.)

71. Varanda, M.G., G. Pinto, and F. Martins, Life cycle analysis of biodiesel production. Fuel Processing Technology, 92(5): p. 1087-94(2011.)

72. Yaakob, Z., et al., Overview of the production of biodiesel from waste cooking oil. Renewable and sustainable energy reviews, 18: p. 184 93(2013.)

73. Leung, D. and Y. Guo, Transesterification of neat and used frying oil: optimization for biodiesel production. Fuel processing technology, 87(10): p. 883-90(2006.)

74. Tier, I., California Biodiesel Multimedia Evaluation. (2012.)

75. Lotero, E., et al., Synthesis of biodiesel via acid catalysis. Industrial \& engineering chemistry research, 44(14): p. 5353-63(2005.) 
76. Liu, X., et al., Transesterification of soybean oil to biodiesel using $\mathrm{SrO}$ as a solid base catalyst. Catalysis Communications, 8(7): p. 1107-11(2007.)

77. Ferrari, R.A., A. Pighinelli, and K.J. Park, Biodiesel production and quality. Biofuel's Engineering Process Technology, 1: p. 221-40(2011.)

78. Li, Z.-H., et al., A stirring packed-bed reactor to enhance the esterificationtransesterification in biodiesel production by lowering mass-transfer resistance. Chemical engineering journal, 234: p. 9-15(2013.)

79. Kawentar, W.A. and A. Budiman, Synthesis of biodiesel from second-used cooking oil. Energy Procedia, 32: p. 190-9(2013.)

80. Huber, G.W., S. Iborra, and A. Corma, Synthesis of transportation fuels from biomass: chemistry, catalysts, and engineering. Chemical reviews, 106(9): p. 4044-98(2006.)

81. Komintarachat, C. and S. Chuepeng, Methanol-based transesterification optimization of waste used cooking oil over potassium hydroxide catalyst. American Journal of Applied Sciences, 7(8): p. 1073-8(2010.)

82. Al-Hamamre, Z. and J. Yamin, Parametric study of the alkali catalyzed transesterification of waste frying oil for Biodiesel production. Energy Conversion and Management, 79: p. 246-54(2014.)

83. Rashid, U. and F. Anwar, Production of biodiesel through optimized alkaline-catalyzed transesterification of rapeseed oil. Fuel, 87(3): p. 26573(2008.)

84. Fadhil, A.B. and L.H. Ali, Alkaline-catalyzed transesterification of Silurus triostegus Heckel fish oil: Optimization of transesterification parameters. Renewable Energy, 60: p. 481-8(2013.)

85. Harabi, M., et al., Biodiesel and Crude Glycerol from Waste Frying Oil: Production, Characterization and Evaluation of Biodiesel Oxidative Stability with Diesel Blends. Sustainability, 11(7): p. 1937(2019.)

86. Rahadianti, E.S., Y. Yerizam, and M. Martha, Biodiesel production from waste cooking oil. IJFAC (Indonesian Journal of Fundamental and Applied Chemistry), 3(3): p. 77-82(2018.)

87. Kafuku, G. and M. Mbarawa, Biodiesel production from Croton megalocarpus oil and its process optimization. Fuel, 89(9): p. 255660(2010.)

88. Lam, M.K., K.T. Lee, and A.R. Mohamed, Homogeneous, heterogeneous and enzymatic catalysis for transesterification of high free fatty acid oil (waste cooking oil) to biodiesel: a review. Biotechnology advances, 28(4): p. 500-18(2010.)

89. de Araújo, C.D.M., et al., Biodiesel production from used cooking oil: A review. Renewable and sustainable energy reviews, 27: p. 445-52(2013.)

90. Atadashi, I., M. Aroua, and A.A. Aziz, Biodiesel separation and purification: a review. Renewable Energy, 36(2): p. 437-43(2011.)

91. Freedman, B., R.O. Butterfield, and E.H. Pryde, Transesterification kinetics of soybean oil 1. Journal of the American Oil Chemists' Society, 63(10): p. 1375-80(1986.)

92. Goff, M.J., et al., Acid-catalyzed alcoholysis of soybean oil. Journal of the American Oil Chemists' Society, 81(4): p. 415-20(2004.)

93. Marinković, D.M., et al., Calcium oxide as a promising heterogeneous catalyst for biodiesel production: Current state and perspectives. Renewable and sustainable energy reviews, 56: p. 1387-408(2016.)

94. Bhatti, H.N., M.A. Hanif, and M. Qasim, Biodiesel production from waste tallow. Fuel, 87(13-14): p. 2961-6(2008.)

95. Farag, H., A. El-Maghraby, and N.A. Taha, Optimization of factors affecting esterification of mixed oil with high percentage of free fatty acid. Fuel Processing Technology, 92(3): p. 507-10(2011.)

96. Saravanan, N., et al., An experimental comparison of transesterification process with different alcohols using acid catalysts. Biomass and bioenergy, 34(7): p. 999-1005(2010.)

97. Carlucci, C., L. Degennaro, and R. Luisi, Titanium dioxide as a catalyst in biodiesel production. Catalysts, 9(1): p. 75(2019.)

98. Soriano Jr, N.U., R. Venditti, and D.S. Argyropoulos, Biodiesel synthesis via homogeneous Lewis acid-catalyzed transesterification. Fuel, 88(3): p. 560-5(2009.)

99. Stamenković, O.S., A.V. Veličković, and V.B. Veljković, The production of biodiesel from vegetable oils by ethanolysis: Current state and perspectives. Fuel, 90(11): p. 3141-55(2011.)

100.Atadashi, I., et al., The effects of catalysts in biodiesel production: A review. Journal of industrial and engineering chemistry, 19(1): p. 14-26(2013.)

101.Ferreira, A.B., A. Lemos Cardoso, and M.J. da Silva, Tin-catalyzed esterification and transesterification reactions: a review. ISRN Renewable Energy, 2012(2012.)

102.Math, M., S.P. Kumar, and S.V. Chetty, Technologies for biodiesel production from used cooking oil-A review. Energy for sustainable Development, 14(4): p. 339-45(2010.)

103.Singh, A.K. and S.D. Fernando, Reaction kinetics of soybean oil transesterification using heterogeneous metal oxide catalysts. Chemical
Engineering \& Technology: Industrial Chemistry-Plant Equipment-Process Engineering-Biotechnology, 30(12): p. 1716-20(2007.)

104.Guo, F., et al., Calcined sodium silicate as solid base catalyst for biodiesel production. Fuel Processing Technology, 91(3): p. 322-8(2010.)

105.Encinar, J.M., A. Pardal, and N. Sánchez, An improvement to the transesterification process by the use of co-solvents to produce biodiesel. Fuel, 166: p. 51-8(2016.)

106.Zabeti, M., W.M.A.W. Daud, and M.K. Aroua, Activity of solid catalysts for biodiesel production: a review. Fuel Processing Technology, 90(6): p. 7707(2009.)

107.Ngamcharussrivichai, C., et al., Biodiesel production through transesterification over natural calciums. Fuel Processing Technology, 91(11): p. 1409-15(2010.)

108.Granados, M.L., et al., Biodiesel from sunflower oil by using activated calcium oxide. Applied Catalysis B: Environmental, 73(3-4): p. 31726(2007.)

109.Xie, W. and T. Wang, Biodiesel production from soybean oil transesterification using tin oxide-supported WO3 catalysts. Fuel processing technology, 109: p. 150-5(2013.)

110.SOLISab, J.L., L. ALEJO, and Y. KIROS, TIN (IV) OXIDE AS SOLID CATALYST FOR HETEROGENEOUS TRANSTESTERIFICATION OF NON-EDIBLE OILS.

111.Kiwjaroun, C., C. Tubtimdee, and P. Piumsomboon, LCA studies comparing biodiesel synthesized by conventional and supercritical methanol methods. Journal of Cleaner Production, 17(2): p. 143-53(2009.)

112.Jain, S. and M. Sharma, Kinetics of acid base catalyzed transesterification of Jatropha curcas oil. Bioresource technology, 101(20): p. 7701-6(2010.)

113.Kusdiana, D. and S. Saka, Kinetics of transesterification in rapeseed oil to biodiesel fuel as treated in supercritical methanol. Fuel, 80(5): p. 693 $8(2001$.

114.Karki, S., et al., Supercritical Transesterification of Waste Vegetable Oil: Characteristic Comparison of Ethanol and Methanol as Solvents. Applied Sciences, 7(6): p. 632(2017.)

115.Farobie, O. and Y. Matsumura, Biodiesel production in supercritical methanol using a novel spiral reactor. Procedia environmental sciences, $\mathbf{2 8}$ p. 204-13(2015.)

116.Yin, J.-Z., M. Xiao, and J.-B. Song, Biodiesel from soybean oil in supercritical methanol with co-solvent. Energy Conversion and Management, 49(5): p. 908-12(2008.)

117.Wei, C.-Y., T.-C. Huang, and H.-H. Chen, Biodiesel production using supercritical methanol with carbon dioxide and acetic acid. Journal of Chemistry, 2013(2013.)

118.Imahara, H., et al., Thermal stability of biodiesel in supercritical methanol. Fuel, 87(1): p. 1-6(2008.)

119.Khan, S.A., et al., Prospects of biodiesel production from microalgae in India. Renewable and sustainable energy reviews, 13(9): p. 2361-72(2009.)

120.Kusdiana, D. and S. Saka, Effects of water on biodiesel fuel production by supercritical methanol treatment. Bioresource technology, 91(3): p. 28995(2004.)

121.Murphy, F., et al., Potential to increase indigenous biodiesel production to help meet 2020 targets-An EU perspective with a focus on Ireland. Renewable and sustainable energy reviews, 35: p. 154-70(2014.)

122.Bajaj, A., et al., Biodiesel production through lipase catalyzed transesterification: an overview. Journal of Molecular Catalysis B. Enzymatic, 62(1): p. 9-14(2010.)

123.Xia, L., Using biosolids as a water source in non-catalytic hydrolysis reactions for biofuel production. (2017.)

124.Günay, M.E., L. Türker, and N.A. Tapan, Significant parameters and technological advancements in biodiesel production systems. Fuel, 250: p. 27-41(2019.)

125.Moazeni, F., Y.-C. Chen, and G. Zhang, Enzymatic transesterification for biodiesel production from used cooking oil, a review. Journal of Cleaner Production, 216: p. 117-28(2019.)

126.Atadashi, I., et al., Refining technologies for the purification of crude biodiesel. Applied energy, 88(12): p. 4239-51(2011.)

127.Albahri, T., M. Riazi, and A. Alqattan, Analysis of quality of the petroleum fuels. Energy \& fuels, 17(3): p. 689-93(2003.)

128.Atadashi, I., M.K. Aroua, and A.A. Aziz, High quality biodiesel and its diesel engine application: a review. Renewable and sustainable energy reviews, 14(7): p. 1999-2008(2010.)

129.Valente, O.S., et al., Physical-chemical properties of waste cooking oil biodiesel and castor oil biodiesel blends. Fuel, 90(4): p. 1700-2(2011.)

130.Abdullahi, M., et al., Removal of free fatty acids in neem oil using diphenylamine functionalized magnetic mesoporous silica SBA-15 for 
biodiesel production. Journal of Petroleum Technology and Alternative Fuels, 7(4): p. 31-7(2016.)

131.Felizardo, P., et al., Production of biodiesel from waste frying oils. Waste Management, 26(5): p. 487-94(2006.)

132.Monyem, A. and J.H. Van Gerpen, The effect of biodiesel oxidation on engine performance and emissions. Biomass and bioenergy, 20(4): p. 31725(2001.)

133.Fernández-Álvarez, P., et al., Evaluation of biodiesel as bioremediation agent for the treatment of the shore affected by the heavy oil spill of the Prestige. Journal of hazardous materials, 147(3): p. 914-22(2007.)

134.Logistics, D.S., Profile of DB Schenker Logistics.
135.Kotrba, R. 'Name that Biodiesel Train' contest. 2013 Feb, 2020]; Available from: http://www.biodieselmagazine.com/blog/article/2013/05/name-thatbiodiesel-train-contest.

136.Clayton. Top 15 Unexpected Uses For Biodiesel. 2019; Available from: https://enrg.io/top-15-unexpected-uses-for-biodiesel/.

137.Center, A.F.D. Diesel Vehicles Using Biodiesel. 2013; Available from: https://afdc.energy.gov/vehicles/diesel.html.

138. Saidur, R., et al., A review on biomass as a fuel for boilers. Renewable and sustainable energy reviews, 15(5): p. 2262-89(2011.)

139.Elgharbawy, A. and A. Sayed, A review on natural gas previous, current and forecasting prices and demand. Journal of Petroleum and Mining Engineering, 22(1): p. 61-4(2020. 